\title{
Rhodococcus fascians in Herbaceous Perennials
}

In the pantheon of plant-pathogenic bacteria, those that are gram positive often receive short shrift, being overshadowed by the more numerous gram-negative species. However, recently we at the Oregon State University Plant Clinic found that one gram-positive bacterial pathogen, Rhodococcus fascians (Tilford 1936) Goodfellow 1984, has been causing persistent problems in the ornamentals industry, specifically in herbaceous perennials. We suspect that leafy gall and shoot proliferations caused by $R$. fascians have been on the rise in recent years due to the high demand for herbaceous perennials, plants that persist for at least 2 years, (generally longer) and lack permanent woody tissue. Herbaceous perennials are and have been a hot segment of the ornamentals market, worth at least three quarters of a billion dollars at the wholesale level during 2005 (1).

Increased demand for herbaceous perennials has driven changes toward high volume production methods using growth hormones to stimulate offshoots for vegetative propagation. The leafy galls and shoot proliferations caused by $R$. fascians can be confused with the denser growth obtained with use of plant hormones. Growers who do not recognize that their plants are diseased risk propagating the bacterium along with their cuttings. The situation is complicated by the ability of the bacterium to persist on plant surfaces for many months prior to the production of symptoms (52).

$R$. fascians and the genus Rhodococcus have been the subject of reviews in recent years that have focused largely on the genetics of the genus $(7,32,57)$ or on the biochemistry of the host-pathogen interactions $(35,103)$. There is little information available on the applied aspects of diseases caused by $R$. fascians. This article focuses on pathogen detection, disease transmission, epidemiology, and management of this persistent disease in nursery production systems.

Corresponding author: M. L. Putnam, Botany and Plant Pathology, Oregon State University, Corvallis 97331; E-mail: putnamm@science.oregonstate.edu

doi:10.1094/PDIS-91-9-1064

(C) 2007 The American Phytopathological Society

\section{Host Range and Geographic Distribution}

$R$. fascians is widely distributed and has been reported from at least 19 states of the United States, Mexico, Canada, Northern Europe, the Middle East, Asia, Australia, and New Zealand; it has been reported on the African continent in Egypt, and in South America in Columbia (2).

$R$. fascians has a reported host range of 87 genera spanning 40 plant families $(2,103)$. Based on our experience, this list, which will likely continue to grow as new hosts are identified, should be expanded to at least 122 taxa (Table 1). The range of susceptible plants is exceptionally broad, encompassing both monocots and dicots and woody as well as herbaceous plants. In comparison, the phytopathogenic bacterium Agrobacterium tumefaciens, also a problem in the ornamentals industry, has a similarly wide host range, but naturally occurring infections are limited to dicotyledonous plants (22).

Many literature reports of hosts of $R$. fascians are based solely on the presence of symptoms, without isolation of the bacterium, much less inoculation and reisolation (required to complete Koch's postulates). Historically, pathogenicity of bacteria recovered from leafy galls was confirmed as the causal agent by inoculating an indicator host, rather than the host of origin, due to difficulties encountered when inoculating the latter. Sweet pea, one of the first reported hosts of $R$. fascians $(50,96)$, has frequently been used as an indicator due to its ease of infection and speed of symptom development (5 to 7 days). In examining host reports and lists, we have found that different criteria have been used for inclusion in host susceptibility listings. In some cases, plants were listed as susceptible based simply on observation of symptoms, e.g., Casuarina equisetifolia (78), Crocus sp. (66), Freesia sp. (98), Fritillaria sp., Hyacinthus sp., Muscari sp. (66), Primula juliae (52), Rhododendron sp. (3), and Viburnum opulus $(8,14)$; these reports should be considered unconfirmed. The status of other plants as hosts could not be clarified due to our inability to find or obtain an original reference. These include Asparagus densiflorus, Capsicum annuum, Chrysanthemum vestitum (2), C. coccineum (=Tanacetum coccineum) (12), Consolida ambigua, Cornus sp. (2), Datura innoxia (12), Erysimum cheiri (3), Euphorbia sp. (12), Ficus benjamina (2), Fragaria vesca (12), Gloriosa sp. (2), Glycine max, Pelargonium $\times$ domesticum, Physalis sp., Piqueria trinervia (12), Pisum sativum var. arvese (2), Rubra speciosa (a name with no official taxonomic standing) (12), Spathiphyllum floribundum (2), Urtica dioica, Verbascum abietinum (12), and Vigna unguiculata (2). Mammillaria theresae, Medicago sativa, and M. truncatula are apparently susceptible (D. Vereecke, personal communication), but reports have not been published. An isolate obtained from fasciated Artemisia vulgaris (4) was of uncertain identity, having some similarities to $R$. fascians, but also to curtobacteria. Additionally, an isolate reported from Phytolacca octandra (76) was later found to have characters inconsistent with those of $R$. fascians and did not hybridize with its DNA (40). Finally, some successful inoculations were made to plants that have never been observed with natural infections. The latter include Acacia mearnsii (81), Anthemis nobilis, Arabidopsis thaliana, Artemisia annua, Atropa belladonna, Catharanthus roseus, Digitalis lanata, Helianthus annuus (101), Kalanchö̈ blossfeldiana (66), Melilotus officinalis (39), Nicotiana plumbaginifolia, Papaver somniferum, Populus tremula $\times P$ alba (101), Pratia nummularia (59), Sesbania rostrata, and Zea mays (101).

We have recently completed Koch's postulates with $R$. fascians isolates from eight hosts not reported previously in the literature: Acanthus mollis, Campanula sarastro, Heliopsis helianthoides, Hosta $\times$ 'Blue Umbrella', Nemesia $\times$ 'Natalie', Verbascum 'Sierra Sunset' (a complex hybrid), Veronica spicata, and Viola $\times$ 'Purple Showers' (80). We have also observed symptoms on and successfully reproduced symptoms with $R$. fascians on Iberis gibraltarica, Oenothera speciosa 'Siskiyou', Cosmos atrosanguineus, Gaura lindheimeri, Tiarella sp., and Sedum spurium (=Phedimus spurious) (Fig. 1). Furthermore, we have isolated $R$. fascians from three other naturally infected hosts not reported in the literature: Argyranthemum sp., Fuchsia sp., and Lavatera sp. These have yet to be tested for pathogenicity. 
For the nursery grower and those working in diagnostic labs, it is often difficult to access the information needed to make decisions on whether a plant might be susceptible to $R$. fascians. In an effort to address this problem and to provide more direct access to relevant information about potential hosts, we have constructed a table listing plants by genus and species, and indicating, where possible, the level of confirmation that the plant in question is a host for $R$. fascians. For each host, we also identify the reference where the plant was first cited (Table 1).

\section{Economic Importance}

$R$. fascians can cause tremendous economic losses that consistently limit profitable production of certain ornamental crops. In 1950, for example, the pathogen was reported to be a limiting factor in commercial culture of Shasta daisy (Leucanthemum $\times$ superbum) 'Esther Read' in California and to occur on certain other ornamentals in most seasons (3). Twenty-five years later, $R$. fascians was still prevalent in the same areas and, in some fields, was present on virtually all plants (73). In contrast, the pathogen appears to occur sporadically on other ornamental crops grown in different production systems. Carnations, reportedly one of the less susceptible species, were affected by the disease in one nursery in England for a period of 10 to 12 years, but at an incidence of only about 5\% (52). In chrysanthemums, incidence varied from 0.5 to $77.7 \%(74,105,106)$, depending on the cultivar. In Dahlia, incidence was as great as $100 \%$ (31).

More recently, we found that disease caused by $R$. fascians can be responsible for serious recurring losses to the nursery industry. One wholesale nursery estimated losses over a 1-year period as great as $\$ 1$ million due to lost sales, recall of infected plants, and time lost in propagating and maintaining material that was eventually destroyed. A second nursery estimated losses due to $R$. fascians at $\$ 394,000$ annually. Other nurseries have had to destroy all plants of a particular cultivar, or have stopped growing particular species or cultivars altogether due to persistent, severe problems with $R$. fascians.

\section{Disease Symptoms}

There has been significant confusion in the industry over diseases caused by $R$. fascians, primarily because the symptoms appear similar to those caused by other agents. The first papers in which leafy galls were described attributed the symptoms to the crown gall bacterium A. tumefaciens $(13,87,105,106)$. Additionally, leafy galls have been attributed to viral infection $(31,39,50,107)$, phytoplasmas (107), viroids (107), insect injury $(25,72)$, genetic causes (25), nematodes (31), chemical substances produced by mixed bacterial populations (50), hormonal disturbance (31), or crowding of plants in small pots (72). In our own experience, growers have attributed symptoms due to $R$. fascians to growth hormones in tissue culture media, aster yellows, virus infection, A. tumefaciens, infestation of eriophyid mites, or exposure to herbicides.

$R$. fascians causes growth abnormalities that are similar to those of plant hormone imbalances. Symptoms in naturally infected plants include proliferation of buds in leaf axils (sometimes described as witches'-brooms) (Fig. 2) or at the base of stems; production of an abnormal number of shoots (Fig. 3); proliferation of partially expanded buds known as leafy galls (Fig. 4); misshapen, thickened leaves or shoots, sometimes termed fasciation; expansion of stems in two dimensions, resulting in ribbon-like growth (fasciation, as more broadly used); adventitious amorphous growth arising from veins, petioles, or leaf edges (Fig. 5); stunting; abnormal scales on bulbs; adventitious roots; and in some cases, root growth inhibition. The degree of symptom expression depends upon the host genus, species, and cultivar $(3,42,50-$ $52,72)$, age at time of infection $(50,53)$, growth conditions (50), and bacterial strain $(26,35,42,66)$. The mode of infection may also influence symptom expression; this is certainly true for artificially inoculated plants in model systems $(35,62)$.

In OSU Plant Clinic submissions, the symptoms we most commonly see associated with $R$. fascians infection are bud or shoot proliferation and leafy galls. Less frequently observed is ribbon-like fasciation, a condition in which stems, flowers, or fruits are flattened. Although $R$. fascians has been reported to produce this type of fasciation $(52,96)$, it is not diagnostic because it may be induced by injury or other disruption of the apical bud $(34,88)$, other infectious agents $(52,88)$, mutations, or it may be a genetically inherited trait (34). We have been unsuccessful in recovering $R$. fascians from woody plants with ribbon-like fasciation (Fig. 6).

The term "leafy gall" was first mentioned in the literature by Williams in 1933 (105), although the cause of the symptom was attributed to A. tumefaciens. Margaret Lacey, an early researcher of $R$. fascians (50), described in detail the leafy gall symptom as consisting of "a number of very short, hypertrophied shoots [which] develop at the base of the plant or cutting, sometimes only just appearing above the soil-level, but spreading horizontally till a large gall-like mass is produced...." In

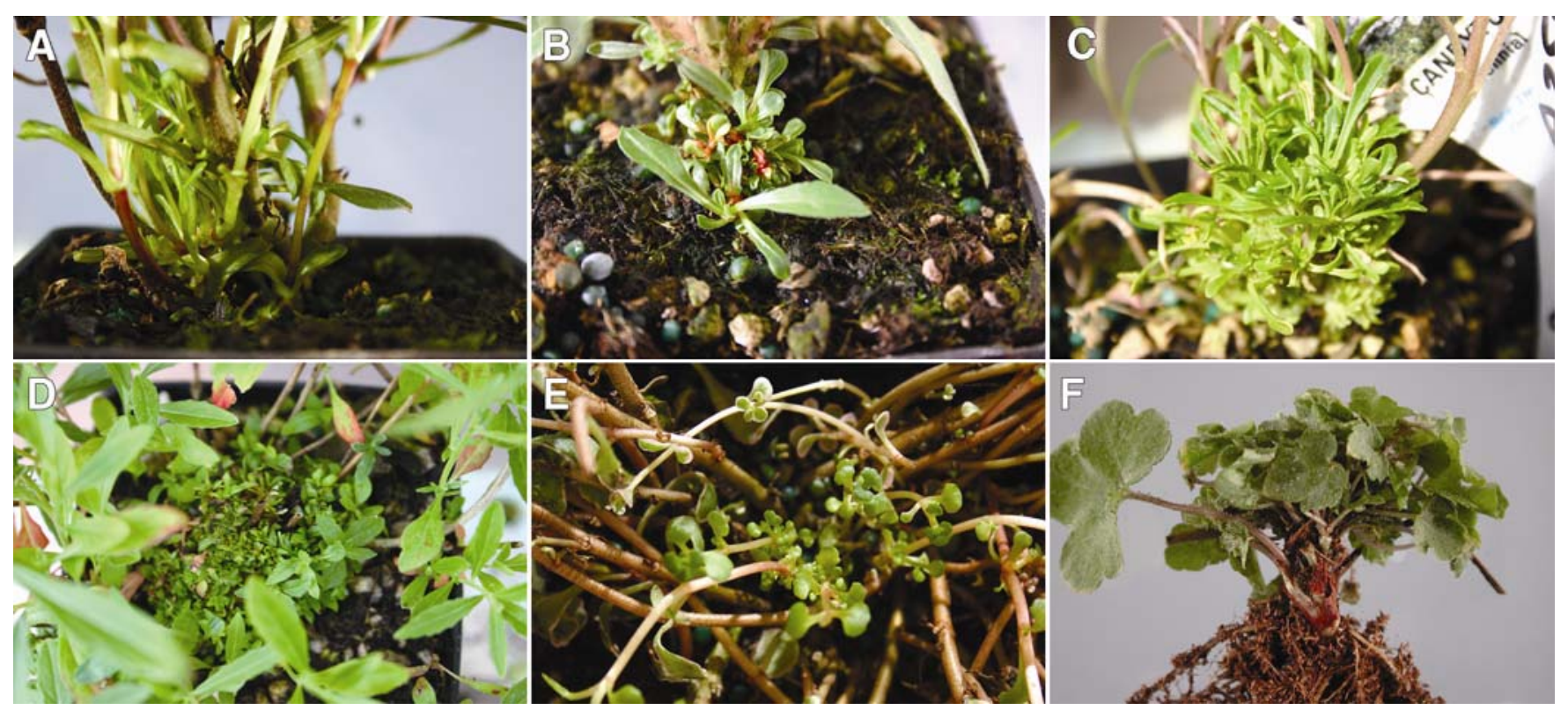

Fig. 1. Symptoms of Rhodococcus fascians on previously unreported hosts. A, Cosmos atrosanguineus; B, Gaura lindheimeri; C, Iberis gibraltarica; D, Oenothera speciosa; E, Sedum spurium; and F, Tiarella sp. 
naturally infected plants, leafy galls are usually formed at the base of the stems or in leaf axils, but in plants such as strawberry, the crown may be affected, resulting in a cauliflower-like growth. A plant usually produces either leafy galls or shoot proliferations, and both are rarely seen in combination.
Leafy galls are composed of masses of well differentiated tissues that are compacted into a small space, a structure that differs from the undifferentiated galls formed by other hyperplasia-inducing phytobacteria such as Pseudomonas syringae subsp. savastanoi, Pantoea agglomerans pv. gypsophilae, or Agrobacterium tumefaciens (Fig. 7). In some plants infected with agrobacteria, tumorlike masses may produce an occasional shoot, but these are produced only sporadically and not in profusion, as with R. fascians.

Table 1. Host range of Rhodococcus fascians

\begin{tabular}{|c|c|c|c|}
\hline Scientific name of host & Family & Diagnosis $^{y}$ & Reference $^{\mathrm{z}}$ \\
\hline Acacia mearnsii & Fabaceae & $\mathrm{e}$ & 81 \\
\hline Acanthus mollis & Acanthaceae & $a, b, c$ & 80 \\
\hline Anthemis nobilis = Chamaemelum nobile & Asteraceae & $\mathrm{e}$ & 101 \\
\hline Antirrhinum majus & Scrophulariaceae & $\mathrm{a}, \mathrm{b}, \mathrm{c}, \mathrm{d}$ & 29 \\
\hline Apium graveolens & Apiaceae & $\mathrm{a}, \mathrm{b}$ & 98 \\
\hline Arabidopsis thaliana & Brassicaceae & $\mathrm{e}$ & 101 \\
\hline Argyranthemum sp. & Asteraceae & $a, b$ & $*$ \\
\hline Artemisia аппиа & Asteraceae & e & 101 \\
\hline Asparagus sprengeri $=$ Asparagus aethiopicus & Liliaceae & $\mathrm{a}, \mathrm{b}, \mathrm{c}, \mathrm{d}$ & 51 \\
\hline Aster $\times$ frikartii & Asteraceae & $a, b$ & 52 \\
\hline Atropa belladonna & Solanaceae & $\mathrm{e}$ & 101 \\
\hline Begonia $\times$ tuberhybrida & Begoniaceae & $\mathrm{f}$ & 39 \\
\hline Beloperone guttata $=$ Justicia brandegeeana & Acanthaceae & $a, b, d$ & 29 \\
\hline Beta vulgaris & Chenopodiaceae & $\mathrm{a}, \mathrm{b}$ & 55 \\
\hline Buddleja davidii & Scrophulariaceae & $\mathrm{f}$ & 74 \\
\hline Campanula $\times$ 'Sarastro' & Campanulaceae & $\mathrm{a}, \mathrm{b}, \mathrm{c}, \mathrm{d}$ & 80 \\
\hline Cardamine triloba $=$ C. amara & Brassicaceae & $\mathrm{a}, \mathrm{b}$ & 52 \\
\hline Carica $\times$ heilbornii $=$ Vasconcellea $\times$ heilbornii & Caricaceae & $\mathrm{g}$ & 76 \\
\hline Carica pubescens $=$ Vasconcellea pubescens & Caricaceae & $\mathrm{g}$ & 76 \\
\hline Catharanthus roseus & Apocynaceae & $\mathrm{e}$ & 101 \\
\hline Cheiranthus allionii $=$ Erysimum $\times$ marshallii & Brassicaceae & $a, b$ & 52 \\
\hline Chrysanthemum indicum & Asteraceae & $a, b$ & 52 \\
\hline Chrysanthemum maximum $=$ Leucanthemum $\times$ superbum & Asteraceae & $\mathrm{a}, \mathrm{b}, \mathrm{c}, \mathrm{d}$ & 52 \\
\hline Chrysanthemum $\times$ morifolium & Asteraceae & $\mathrm{e}$ & 66 \\
\hline Chrysanthemum sp. & Asteraceae & $a, b, e$ & 96 \\
\hline Cichorium endivia crispa $=$ Cichorium endivia subsp. endivia & Asteraceae & $\mathrm{a}, \mathrm{b}, \mathrm{c}, \mathrm{d}$ & 31 \\
\hline Cichorium endivia latifolia $=$ Cichorium endivia subsp. endivia & Asteraceae & $\mathrm{a}, \mathrm{b}, \mathrm{c}, \mathrm{d}$ & 31 \\
\hline Cichorium intybus & Asteraceae & $\mathrm{a}, \mathrm{b}, \mathrm{d}$ & 41 \\
\hline Cicer arietinum & Fabaceae & $\mathrm{e}$ & 41 \\
\hline Cosmos atrosanguineus & Asteraceae & $\mathrm{e}$ & 80 \\
\hline Cucumis sativus & Cucurbitaceae & $a, b, c, d$ & 31 \\
\hline Dahlia sp. A101 & Asteraceae & $a, b, d$ & 52 \\
\hline Dahlia variabilis $=$ D. pinnata & Asteraceae & $\mathrm{a}, \mathrm{b}, \mathrm{d}$ & 98 \\
\hline Delphinium sp. & Ranunculaceae & $a, b$ & 52 \\
\hline Dianthus barbatus & Caryophyllaceae & $\mathrm{a}, \mathrm{b}, \mathrm{d}$ & 52 \\
\hline Dianthus sp. (presumably D. caryophyllus) & Caryophyllaceae & $\mathrm{a}, \mathrm{b}, \mathrm{d}$ & 50 \\
\hline Digitalis lanata & Scrophulariaceae & $\mathrm{e}$ & 101 \\
\hline Erysimum asperum & Brassicaceae & $\mathrm{a}, \mathrm{b}, \mathrm{d}$ & 52 \\
\hline Euphorbia pulcherrima & Euphorbiaceae & $\mathrm{a}, \mathrm{b}, \mathrm{d}$ & 66 \\
\hline Forsythia suspensa & Oleaceae & $a, b$ & 52 \\
\hline Fragaria $\times$ ananassa & Rosaceae & $\mathrm{a}, \mathrm{b}, \mathrm{d}$ & 50 \\
\hline Fragaria sp. & Rosaceae & $\mathrm{a}, \mathrm{b}$ & 52 \\
\hline Fuchsia sp. & Onagraceae & $\mathrm{a}, \mathrm{b}$ & $*$ \\
\hline Gaura lindheimeri & Onagraceae & $\mathrm{e}$ & $*$ \\
\hline Gladiolus sp. & Iridaceae & $\mathrm{a}, \mathrm{b}, \mathrm{c}, \mathrm{d}$ & 51 \\
\hline Gypsophila paniculata & Caryophyllaceae & $\mathrm{e}$ & 96 \\
\hline Hebe andersonii & Scrophulariaceae & $\mathrm{a}, \mathrm{b}, \mathrm{d}$ & 66 \\
\hline Hebe elliptica & Scrophulariaceae & $\mathrm{a}, \mathrm{b}, \mathrm{d}$ & 16 \\
\hline Hebe speciosa & Scrophulariaceae & $\mathrm{a}, \mathrm{b}, \mathrm{d}$ & 16 \\
\hline Helianthus annuus & Asteraceae & $\mathrm{e}$ & 101 \\
\hline Heliopsis helianthoides & Asteraceae & $\mathrm{a}, \mathrm{b}, \mathrm{d}$ & 80 \\
\hline Heuchera sanguinea & Saxifragaceae & $a, b, c$ & 51 \\
\hline Hosta sp. & Liliaceae & $\mathrm{a}, \mathrm{b}$ & 80 \\
\hline Iberis gibraltarica & Brassicaceae & $\mathrm{e}$ & $*$ \\
\hline
\end{tabular}

(Continued on next page)

y Diagnostic methods: a, observation of symptoms; b, isolation of $R$. fascians; c, inoculation of $R$. fascians to original host; d, inoculation of $R$. fascians to indicator host (pea or sweet pea); e, inoculation of $R$. fascians for host range studies; $\mathrm{f}$, inoculation of tissue macerate from symptomatic plant; g, isolates of $R$. fascians deposited to culture collection from this host; no other data given.

$\mathrm{z} *$ Isolations and/or inoculations by M. Putnam and M. Miller, unpublished. ** D. Vereecke, personal communication. 
Symptoms caused by $R$. fascians are not always as severe or grotesque as those already described. Some plants from which we have recovered pathogenic $R$. fascians have shown only a minor increase in the number of axillary shoots (Fig. 8). Leafy galls, especially those at the crown or near soil level, can retain water and become a suitable environment for invasion by opportunistic fungi and bacteria such that breakdown of the affected tissue occurs $(3,31)$. Although we have observed secondary infection in some plants, we have maintained many specimens with leafy galls for years in the absence of secondary disease.

Root growth is affected in some hosts under conditions of artificial inoculation $(26,101,103)$; the main roots may be thickened, and secondary roots may be inhibited resulting in a reduced root system

Table 1. (Continued from previous page)

\begin{tabular}{|c|c|c|c|}
\hline Scientific name of host & Family & Diagnosis $^{\mathrm{y}}$ & Reference $^{\mathrm{z}}$ \\
\hline Iberis sempervirens & Brassicaceae & $\mathrm{a}, \mathrm{b}, \mathrm{d}$ & $*$ \\
\hline Impatiens walleriana & Balsaminaceae & $\mathrm{a}, \mathrm{b}, \mathrm{d}$ & 16 \\
\hline Ipomoea purpurea & Convolvulaceae & $a, b, c$ & 31 \\
\hline Kalanchoë blossfeldiana & Crassulaceae & $\mathrm{a}, \mathrm{b}, \mathrm{d}$ & 66 \\
\hline Lactuca sativa & Asteraceae & $\mathrm{a}, \mathrm{b}, \mathrm{c}, \mathrm{d}$ & 31 \\
\hline Lathyrus odoratus & Fabaceae & $\mathrm{a}, \mathrm{b}, \mathrm{c}$ & 96 \\
\hline Lavatera sp. & Malvaceae & $\mathrm{a}, \mathrm{b}$ & $*$ \\
\hline Lilium longiflorum & Liliaceae & $\mathrm{a}, \mathrm{b}, \mathrm{c}, \mathrm{e}$ & 28 \\
\hline Lilium regale & Liliaceae & $\mathrm{a}, \mathrm{b}$ & 52 \\
\hline Lilium speciosum & Liliaceae & $a, b, c, d$ & 66 \\
\hline Lycopersicon esculentum & Solanaceae & $a, b, c, d$ & 31 \\
\hline Mammillaria theresae & Cactaceae & $\mathrm{e}$ & $* *$ \\
\hline Medicago sativa & Fabaceae & $\mathrm{e}$ & $* *$ \\
\hline Medicago truncatula & Fabaceae & $\mathrm{e}$ & $* *$ \\
\hline Melilotus officinalis & Fabaceae & $\mathrm{f}$ & 39 \\
\hline Mesembryanthemum sp. & Euphorbiaceae & $\mathrm{a}, \mathrm{b}$ & 29 \\
\hline Nemesia sp. & Scrophulariaceae & $\mathrm{a}, \mathrm{b}, \mathrm{d}$ & 80 \\
\hline Nicotiana afinis $=N$. alata & Solanaceae & $a, b, c, d$ & 31 \\
\hline Nicotiana clevelandii & Solanaceae & $\mathrm{f}$ & 39 \\
\hline Nicotiana glutinosa & Solanaceae & $\mathrm{a}, \mathrm{b}, \mathrm{c}, \mathrm{d}$ & 51 \\
\hline Nicotiana megalosiphon & Solanaceae & $\mathrm{e}, \mathrm{f}$ & 39 \\
\hline Nicotiana plumbaginifolia & Solanaceae & $\mathrm{e}$ & 101 \\
\hline Nicotiana rustica & Solanaceae & $\mathrm{e}$ & 39 \\
\hline Nicotiana tabacum & Solanaceae & $\mathrm{e}$ & 96 \\
\hline Nierembergia sp. & Solanaceae & $a, b$ & * \\
\hline Oenothera speciosa & Onagraceae & $\mathrm{e}$ & $*$ \\
\hline Papaver somniferum & Papaveraceae & $\mathrm{e}$ & 101 \\
\hline Pelargonium $\times$ hortorum & Geraniaceae & $a, b, c, d$ & 93 \\
\hline Pelargonium zonale & Geraniaceae & $b, d$ & 66 \\
\hline Pelargonium sp. & Geraniaceae & $\mathrm{a}, \mathrm{b}, \mathrm{c}$ & 96 \\
\hline Petunia Mitchell MD1 & Solanaceae & $\mathrm{e}$ & 28 \\
\hline Petunia sp. & Solanaceae & $\mathrm{a}, \mathrm{b}$ & 52 \\
\hline Phaseolus multiflorus $=P$. coccineus & Fabaceae & $\mathrm{a}, \mathrm{b}$ & 52 \\
\hline Phaseolus vulgaris & Fabaceae & $\mathrm{e}$ & 52 \\
\hline Phlox sp. & Polemoniaceae & $\mathrm{a}, \mathrm{b}, \mathrm{d}$ & 29 \\
\hline Pisum sativum & Fabaceae & $\mathrm{a}, \mathrm{b}, \mathrm{d}$ & 96 \\
\hline Populus tremula $\times$ P. alba & Salicaceae & $\mathrm{e}$ & 101 \\
\hline Pratia nummularia & Campanulaceae & $\mathrm{e}$ & 59 \\
\hline Primula sp. & Primulaceae & $\mathrm{a}, \mathrm{b}, \mathrm{d}$ & 41 \\
\hline Ricinus sanguineus & Euphorbiaceae & $\mathrm{e}$ & 31 \\
\hline Rubus idaeus & Rosaceae & $\mathrm{a}, \mathrm{b}, \mathrm{d}$ & 43 \\
\hline Schizanthus grandiflora & Solanaceae & $\mathrm{e}$ & 52 \\
\hline Schizanthus pinnatus & Solanaceae & $\mathrm{e}$ & 52 \\
\hline Schizanthus retusus & Solanaceae & $\mathrm{a}, \mathrm{b}, \mathrm{d}$ & 50 \\
\hline Sedum spurium $=$ Phedimus spurius & Crassulaceae & $\mathrm{e}$ & $*$ \\
\hline Sesbania rostrata & Fabaceae & $\mathrm{e}$ & 101 \\
\hline Solanum tuberosum & Solanaceae & $a, b$ & 55 \\
\hline Spinacia oleracea & Chenopodiaceae & $\mathrm{a}, \mathrm{b}, \mathrm{c}$ & 31 \\
\hline Tagetes erecta & Asteraceae & $a, b, c, d$ & 31 \\
\hline Tagetes patula & Asteraceae & $\mathrm{a}, \mathrm{b}, \mathrm{c}, \mathrm{d}$ & 31 \\
\hline Tiarella $\mathrm{sp}$. & Saxifragaceae & $\mathrm{e}$ & $*$ \\
\hline Tropaeolum majus & Tropaeolaceae & $a, b$ & 52 \\
\hline Tulipa gesneriana & Liliaceae & $a, b$ & 29 \\
\hline Verbascum densiflorum & Scrophulariaceae & $\mathrm{a}, \mathrm{b}$ & 52 \\
\hline Verbascum nigrum & Scrophulariaceae & $a, b, c, d$ & 66 \\
\hline Verbascum sp. & Scrophulariaceae & $\mathrm{a}, \mathrm{b}, \mathrm{d}$ & 70 \\
\hline Verbascum $\times$ 'Sierra Sunset' & Scrophulariaceae & $\mathrm{a}, \mathrm{b}, \mathrm{d}$ & 80 \\
\hline Verbascum vernale & Scrophulariaceae & $\mathrm{f}$ & 74 \\
\hline Verbena sp. & Verbenaceae & $\mathrm{a}, \mathrm{b}$ & 29 \\
\hline Veronica spicata & Scrophulariaceae & $\mathrm{a}, \mathrm{b}, \mathrm{c}, \mathrm{d}$ & 80 \\
\hline Vicia faba & Fabaceae & $\mathrm{e}$ & 52 \\
\hline Viola sp. & Violaceae & $a, b$ & $*$ \\
\hline Zea mays & Poaceae & $\mathrm{e}$ & 101 \\
\hline
\end{tabular}




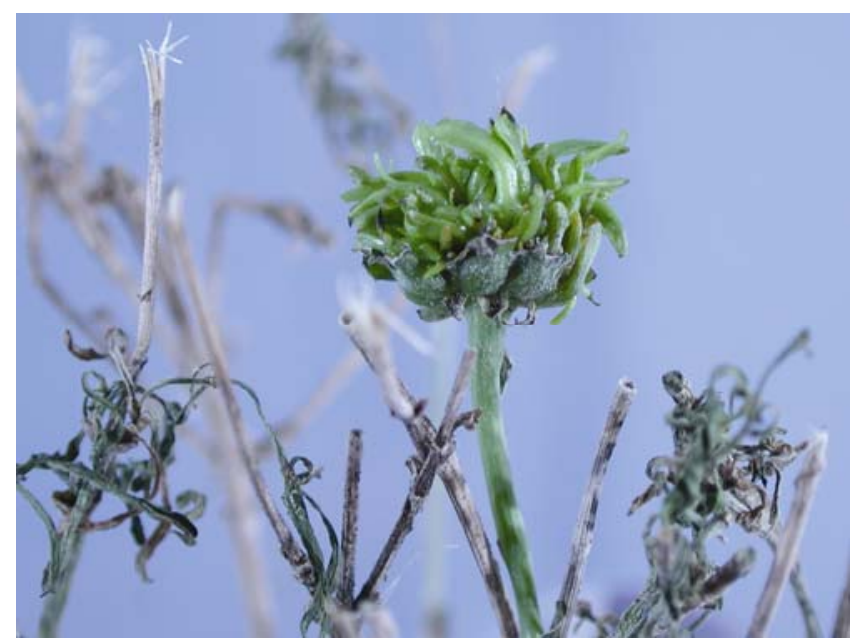

Fig. 2. An aerial leafy gall of Coreopsis, a typical symptom of infection by Rhodococcus fascians.

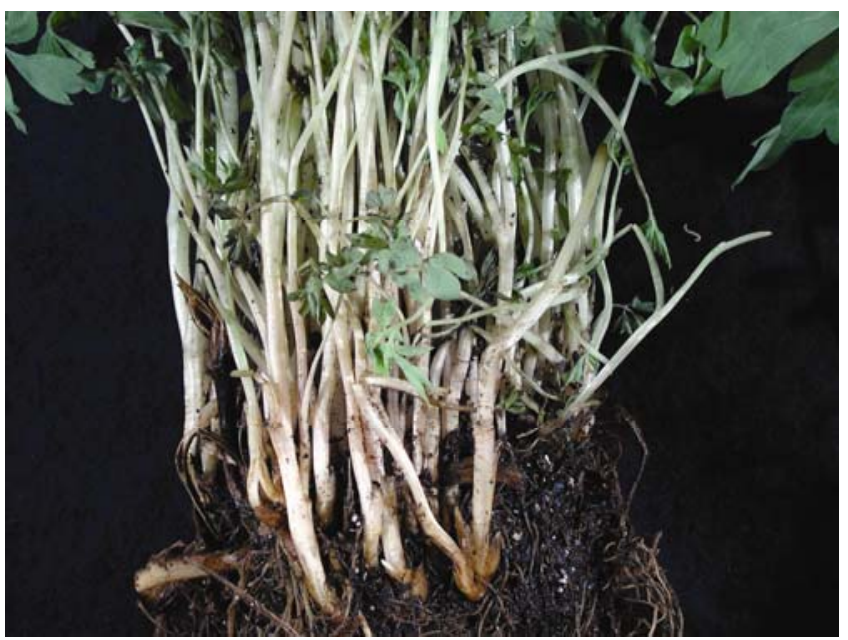

Fig. 3. Shoot proliferation of Dicentra infected with Rhodococcus fascians. overall. Atrophy of secondary roots occurs also in tomato, pea, and cucumber (31). Galls comprised of tightly compressed masses of buds have been reported on naturally infected raspberry roots in Scotland (43), the first and only report of its kind. In naturally infected lilies, deformed bulbs produced reduced root growth, but plants that showed only symptoms aboveground generally had well developed root systems (66).

\section{The Genus Rhodococcus}

Rhodococcus species are gram positive, aerobic, non-spore forming, nonmotile bacteria with cell walls containing mycolic acids (38). The cells are nocardioform, meaning they may have mycelial growth with fragmentation into rod-shaped or coccoid forms (7). Rhodococcus has been placed in the order Actinomycetales, suborder Corynebacterineae, and along with Nocardia, belongs to the family Nocardiaceae (36). Rhodococcus is closely related to the genus Corynebacterium, which contains both plant and animal pathogens, and Mycobacterium, a genus containing human and animal pathogens. The taxonomy of the coryneform bacteria has shifted with time, and placement of individual members has been uncertain, with individual species being moved between Corynebacterium, Mycobacterium, Nocardia, and Rhodococcus. Both Rhodococcus and Nocardia have many features similar to those of soilborne actinomycetes such as Streptomyces (57), and recently Streptomyces turgidiscabies has been found to have a pathogenicity island containing genes homologous to the fas operon in $R$. fascians (47).

The genus Rhodococcus is genetically diverse and well adapted to the soil environment $(32,36,57)$. Various species are of interest as degraders of hydrocarbons in soil, including chloroaromatics, nitroaromatics, and polychlorobiphenyls $(6,7)$; the genus contains at least one animal and opportunistic human pathogen ( $R$. equi)

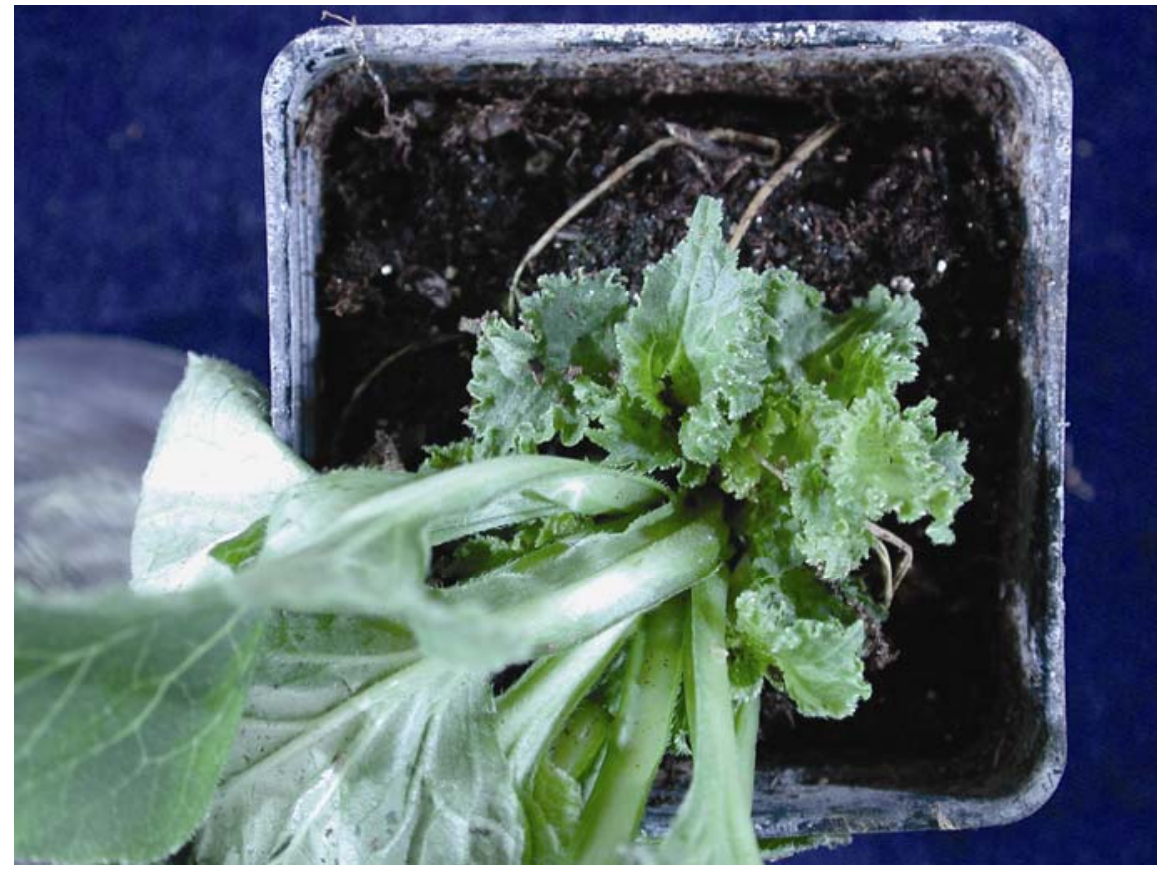

Fig. 4. Rhodococcus fascians often causes basal leafy galls, as shown on this Campanula.

(32), as well as the phytopathogen $R$. fascians. Bacterial isolates identified as $R$. fascians have been found in diverse habitats, including polar seas (65) and 120,000year-old ice sediments in Greenland (69), in fly-induced lesions in sheep (48), the larval cuticle of obligate parasitic flies (97), and the rinds of some German cheeses (99). Two isolates have been reported as fixing nitrogen (30). None of these isolates have been examined for phytopathogenicity, however. As a group, the rhodococci have a tolerance for starvation $(10,104)$ which may aid in their persistence in soil.

\section{Pathogenesis}

Virulent isolates of $R$. fascians possess a large conjugative linear plasmid of about $200 \mathrm{~kb}(19,20,77)$ that bears at least three loci required for pathogenicity $(19,103)$ The determinants of pathogenicity on the plasmid pFiD188 (for fasciation inducing) in strain D188, the most intensively studied isolate, reside within the fas, att, and hyp operons. The fas locus contains six genes that encode an isopentenyl transferase (IPT), plus enzymes that modify the product, and overall produces an unknown molecule that stimulates symptom development $(19,20,102)$. The att and hyp loci regulate symptom severity $(17,19)$. A fourth locus involved in pathogenicity, vic, has been identified on the bacterial chromosome and is associated with the ability of $R$. fascians to utilize the glyoxylate shunt of the Krebs cycle as an alternate pathway for catabolism of specific nutrients (102). These bacteria may be capable of either altering their nutritional require- 
ments while inside the host tissue, or influencing the array of metabolic compounds produced within the plant, or both. This could confer a distinct adaptive advantage over other bacteria in the same environment (102).

Leafy galls are structures characterized by an alteration of apical dominance leading to the development of multiple buds that are inhibited soon after formation (101). Although it was initially thought that only meristematic cells could be affected (51), later researchers found that any somatic cell capable of dividing could be stimulated to form new tissues (101). Leafy galls are initiated when outer cortical cells are stimulated by the pathogen to divide and form a meristem, which then develops into a shoot primordium (63). In model systems, shoot elongation is inhibited, leading to leafy galls. The exact nature of the chemicals that induce generation of new buds remains unknown (103). The symptoms are similar to those induced by cytokinins, and multiple cytokinins can be isolated from supernatants of $R$. fascians cell cultures, but the amounts of classical cytokinins produced by $R$. fascians in culture are too low to account for leafy gall symptoms $(27,103)$. In addition, the levels of cytokinins produced in axenic cultures of virulent isolates are only moderately greater than those produced by avirulent isolates, suggesting the increase alone is not sufficient for pathogenicity (27). It is presumed that a cytokinin-like compound is produced by the bacteria, or that in planta, the close proximity of cytokinins produced by the bacteria have a greater impact on plant cells than those isolated from culture supernatants and applied in bioassays (27).

$R$. fascians resides primarily on the exterior surfaces of plants. Cornelis et al. (18) verified early observations by Lacey (51) using scanning electron microscopy and in situ hybridization. They found bacteria residing in cavities on the leaf surface and at the junctions of epidermal cell walls. Unlike most other plant-pathogenic bacteria, stomata and hydathodes did not appear to be important for bacterial ingress. The bacteria were apparently not limited to the intercellular spaces but several times were observed surrounded by a single cell wall, indicating intracellular penetration. There were far more bacteria observed on the exterior than in the interior of plants, however, and no bacterial cells were observed in vascular tissues of tobacco or Arabidopsis (18). R. fascians is not considered to be systemic in plants $(35,51,101)$.

Cornelis et al. propose the following model of infection: $R$. fascians grows epiphytically on aerial plant surfaces, where it is protected by a bacterial slime layer. The bacteria cause a collapse of some epidermal cells, and thereby penetrate the plant. The surface bacteria produce a signal or

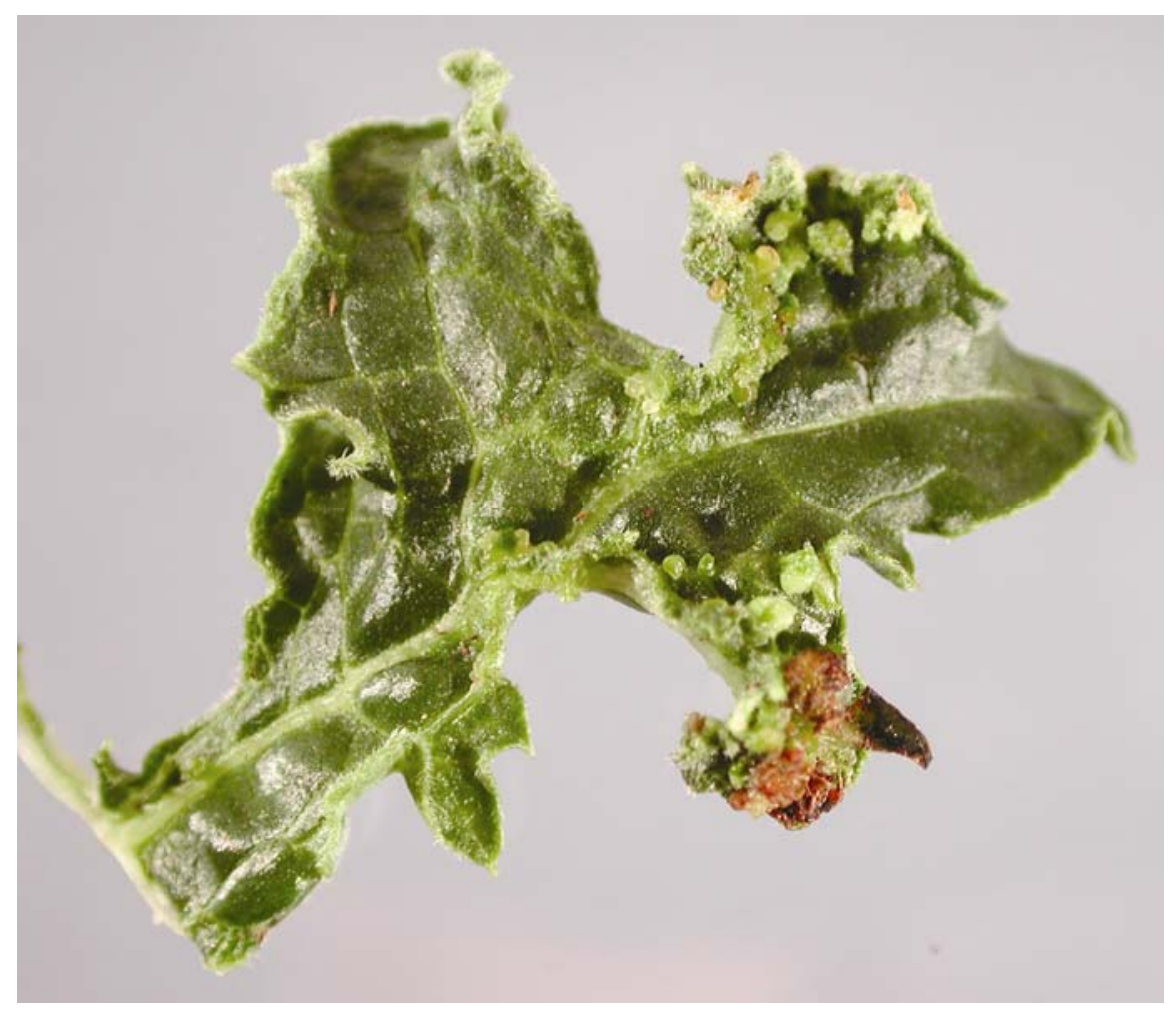

Fig. 5. Rhodococcus fascians infected Acanthus mollis leaf showing foliar distortion and generation of adventitious tissue.

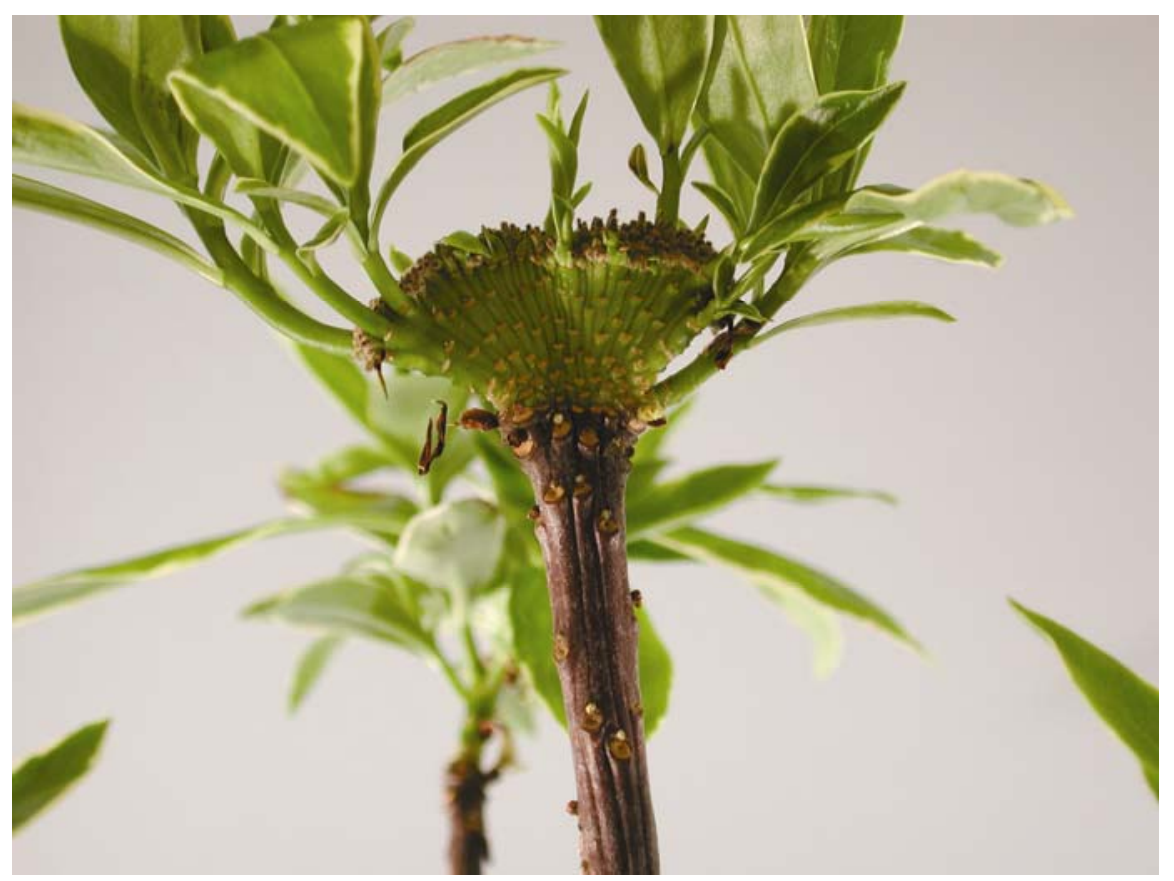

Fig. 6. Fasciation of Daphne odora. No Rhodococcus fascians was recovered or detected.

signals that initiate symptom development including de novo meristem generation, or activation of existing meristems, resulting in the production of a leafy gall (18).

\section{Disease Transmission}

In our experience, growers have more questions about movement and survival of $R$. fascians than there are answers in the literature. We are in the process of examin- ing some ways in which these bacteria may spread in greenhouses.

Soil. Members of the genus Rhodococcus are considered to be soilborne $(7,38)$, but whether $R$. fascians is a true soil resident or merely a transient is unknown. $R$. fascians has been revived from ancient soil sediments in arctic ice (69), suggesting it is adapted to long-term survival in soils at low temperatures. However, its longevity 
in field soils in temperate climates has not been definitively established. In a small pot trial, $R$. fascians persisted on infected plant material buried in nonirrigated soil for 3 months (73), but did not persist in the absence of intact plant material. From these data, the author concluded the bacterium is not a soil resident but is present only as long as host tissue remains.

$R$. fascians may have greater ability to survive in soil than was previously suspected. Boylen and Mulks (10) found that $R$. fascians endured 56 days of starvation with low respiration, and that populations recovered quickly once nutrients were restored. This suggests the species is well adapted to survive periods of nutrient stress in soil and may be able to persist from one season to another. In France, $R$. fascians could be recovered from soil in a cold frame 8 months after initial detection, and it was speculated that these bacteria can remain viable in field soil for at least 4 or 5 years "if appropriate conditions are achieved" (31). In greenhouses especially, where multiple crops are grown over the course of a year, infested soil could be an important means of contaminating a new crop.

Seed. $R$. fascians is known to be seedborne in some hosts such as pea (96) and Schizanthus retusus (52). Baker (3) observed an increased number of symptoms in nasturtium (Tropaeolum majus) seeds planted in pasteurized soil, which he attributed to $R$. fascians. He conjectured that the developing seeds acquired the bacteria when drooping flower stalks rested on contaminated soil. Anecdotes from growers suggest that $R$. fascians may be carried on the seed of commercial greenhouse geraniums (Pelargonium spp.), Petunia hybrids, Marguerite daisy (Argyranthemum), and carnation (Dianthus spp.). The extent to which the bacterium is seedborne in other crops is unknown. Given that these bacteria are not known to colonize the vascular tissue, it is likely that the bacteria occur on the seed coat, rather than in the interior of the seed.

Propagation material. Most herbaceous ornamentals are propagated vegetatively, usually from cuttings, but some- times root divisions are used as well. Contaminated propagation material is probably the primary means by which $R$. fascians is introduced into new areas, including previously uninfested fields or greenhouses. Root divisions of Shasta daisy were found to be a major source of $R$. fascians inoculum in a field situation (73). In order to maximize production, growers often want to propagate from healthy portions of symptomatic plants and have asked if it is safe to do so. Although the pathogen has not been observed in the vascular system of plants, few species have been thoroughly examined. In France, cuttings taken from diseased dahlias produced large leafy galls, and tuber production was much reduced (31). We have made some preliminary investigations into the distribution of $R$. fascians in plants and were able to detect the pathogen in seemingly healthy shoots of a Nemesia plant with shoot proliferation. This result suggests it would be imprudent to take cuttings from apparently healthy tissue of an infected plant.

Plants derived from tissue culture are often touted as a source of pathogen-free propagation material. This may not always be true. On more than one occasion we have isolated pathogenic $R$. fascians from symptomatic plant material still growing in vitro.

Vectors. Under artificial conditions, $R$. fascians was transmitted to Nicotiana megalosiphon at a low level of incidence by starved aphids that had fed on Nicotiana tabacum plants with leafy galls (39). Bacteria identified as $R$. fascians have been found inhabiting the cuticle of flies that parasitize sheep (97), which suggests that the bacteria may be carried by other insects as well. The role of insects in natural disease transmission is unknown.

Water. Water is important in dissemination of $R$. fascians, as it is in other bacterial diseases. Disease incidence approached $100 \%$ when Shasta daisies were grown in irrigation ditches, leading Baker (3) to conclude that these bacteria move in surface water in field situations. Growers have reported an increased incidence of symptomatic plants in greenhouse benches

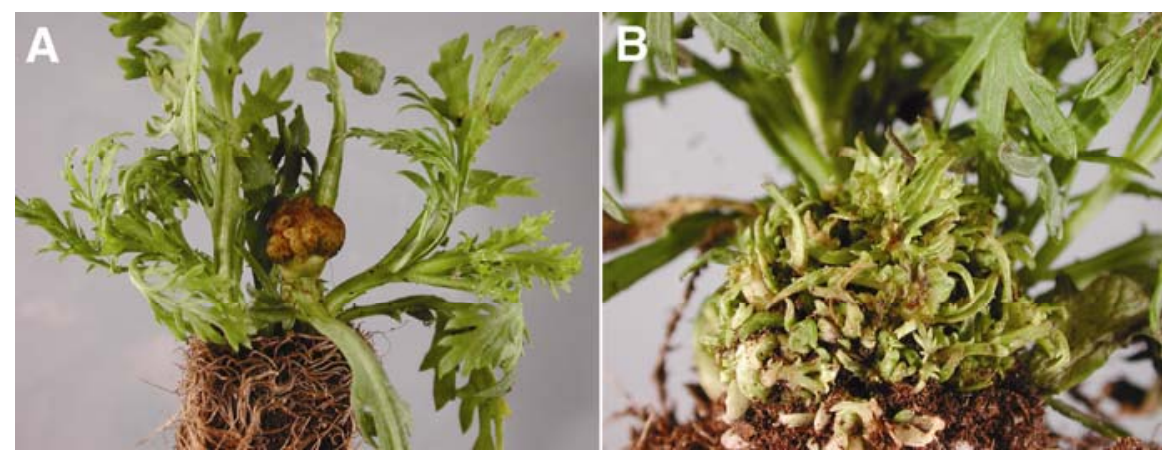

Fig. 7. Argyranthemum infected by: A, Agrobacterium tumefaciens, and B, Rhodococcus fascians. Leafy galls due to infection by $R$. fascians differ significantly in structure from the undifferentiated galls caused by $A$. tumefaciens. that are flood irrigated, suggesting that $R$. fascians is carried in irrigation water in greenhouse situations as well. Splash from overhead irrigation or rain is also likely to be important in local (short distance) spread of the pathogen.

Environmental factors and disease. The temperature optimum for $R$. fascians is 25 to $28^{\circ} \mathrm{C}$, with a maximum over $35^{\circ} \mathrm{C}$ and a minimum below $7^{\circ} \mathrm{C}$ (96). Higher temperatures (above $33^{\circ} \mathrm{C}$ ) seem to inhibit or at least severely reduce infection (31), limiting disease spread in geographic regions with warm summers.

Recovery of $R$. fascians from ice (69) and polar seawater (65) indicates it can survive for considerable periods at low temperatures. This is important since some perennials require a chilling period to initiate flower development, and growers who expect these bacteria to be destroyed by such treatment will be disappointed.

Faivre-Amiot noted that moist soil and humid climate are favorable for aerial infections (31), and Baker (3) speculated that the reason there was not more infection of sweet peas in California was due to the arid climate during the summer. Moderately warm temperatures favor disease development, and heavy overhead irrigation can result in increased disease incidence and severity (3). In our own experiments, we have noticed increased disease when inoculated plants are covered with clear plastic bags for several days to increase the humidity and reduce drying of the plant surfaces.

There is no information available on the ability of $R$. fascians to withstand ultraviolet light, dehydration, or other environmental stresses present when bacteria inhabit leaf surfaces. Nevertheless, the yellow-orange pigment of the bacterium may protect it from UV light (93), and the

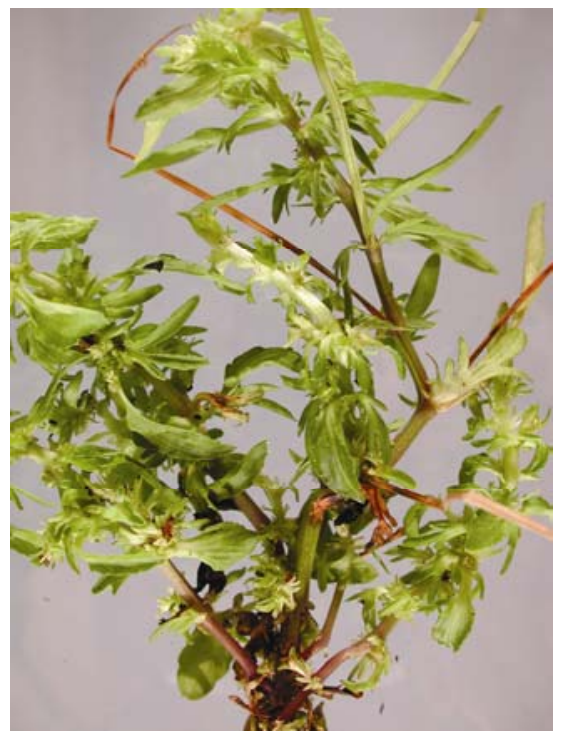

Fig. 8. Stimulation of axillary buds of Viola 'Molly Sanders' infected by Rhodococcus fascians. Symptoms of infected plants can be subtle. 
occurrence of a slime layer $(18,51)$ suggests the formation of a biofilm, which may shield the inhabitants from environmental extremes. However, even in the absence of such a highly organized structure, the slime layer may keep the bacteria from desiccating, as it does in other bacterial epiphytes (5).

\section{Diagnosis and Detection of the Pathogen}

We initially became interested in $R$. fascians when growers began sending us plants with leafy galls and asking for confirmation of crown gall disease. Although symptoms were not at all typical of crown gall, we frequently recovered agrobacteria from surface-disinfected plants with bud and shoot proliferation or leafy galls. These Agrobacterium isolates all proved to be avirulent, however (68). In contrast, nearly all the $R$. fascians isolates we recovered from leafy galls produced symptoms on test plants. This conflation of leafy gall with crown gall is common in the ornamentals industry, and diagnosticians must be aware that the association of agrobacteria with leafy galls and shoot proliferations does not confirm causality. Diagnosis is also complicated by the similarity of symptoms caused by $R$. fascians and exogenously applied growth hormones (Fig. 9), which are commonly used in production of herbaceous ornamentals. Diagnosis must be confirmed, at a minimum, by isolation of $R$. fascians and inoculation to a susceptible host. It is important to confirm pathogenicity of an isolate identified as $R$. fascians, since avirulent isolates can be recovered from plants (98), including asymptomatic plants (55).

Methods used to identify and detect $R$. fascians include classical physiological and biochemical tests, carbon source utilization (Biolog, Hayward, CA; BioMérieux, Durham, NC), fatty acid analysis, DNA colony hybridization (40), serological methods, and the polymerase chain reaction (PCR) (89). Each of these procedures has drawbacks, and isolates may be accidentally excluded due to the variability among strains.

In our laboratory, we rely upon multiple methods to identify $R$. fascians. Colonies are screened for the proper morphology on D2 medium (44), then are streaked multiple times to ensure we have an axenic culture. The "purified" bacteria are then tentatively identified using Biolog, assayed using our PCR primers (see below) to determine if the isolate carries virulence genes, and inoculated onto several indicator plants. To confirm the identity of isolates, we are sequencing $16 \mathrm{~S}$ ribosomal DNA and comparing the sequences to those of reference cultures of $R$. fascians.

Isolation. Researchers have reported difficulty in isolating $R$. fascians $(31,39)$, largely because they were using a vigorous surface disinfection prior to isolations. The majority of $R$. fascians cells reside on the surface of infected tissues, and treatment by flaming or using chemical disinfectants greatly reduces the number of viable bacteria (51). In our experience, even washing in tap water (5 to $10 \mathrm{~min}$ ) can reduce the recovery of $R$. fascians from symptomatic plants.

Many methods of isolation have been published $(11,50,66,83,94,96,98)$. In the OSU Plant Clinic, we have had good success by removing visible soil particles from affected tissues by brief rinsing in tap water, then placing small pieces of symptomatic whole tissue ( 2 to $3 \mathrm{~mm}$ ) in saline containing $0.02 \%$ ( vol/vol) cycloheximide and incubating for 30 to $120 \mathrm{~min}$ at room temperature. The resulting suspension is streaked or diluted and spread onto plates of D2 medium (44) and incubated at $27^{\circ} \mathrm{C}$. The plates are examined after 5 days. $R$. fascians grows more slowly than other surface-residing bacteria and can be missed if present in low numbers, overgrown by more vigorous bacteria, or if isolation plates are observed prematurely. $R$. fascians grows as small, round, entire, convex, opaque, botryose, glistening colonies which are initially cream colored, deepening to chrome yellow after about 7 days. Pigments in strain $2 \mathrm{Y}$ have been analyzed and found to have 13 different carotenoid compounds (79). Pigment production was enhanced by the addition of valine at $0.1 \%$ or an increase in mannitol from 1 to $3 \%$ (79). White mutants have been described $(18,42)$ and were also generated by irradiation (41). None of the irradiated mutants lost virulence, indicating that pigment formation is not associated with the ability to infect plants (41).
Pink, yellow, and deep orange mutants have also been generated (23). Growth on media containing at least $1 \%$ fermentable sugar will be spreading and mucoid. "Rough" colonies, being relatively large, flat, dull, dry, and wrinkled may appear in aged cultures or on media containing certain salts (70), or on media containing peptone (55), and this trait appears to be stable once it arises $(54,55,70)$. $R$. fascians grows well on many general nutrient media, as long as they contain thiamine at a minimum concentration of $1 \mathrm{ppm}$ (95). These bacteria grow equally well from $\mathrm{pH}$ 5.0 to 8.5 in vitro (95).

We have on occasion experienced difficulty in isolating $R$. fascians from symptomatic plants, even after multiple attempts. Lacey (56) thought the inability to recover bacteria from symptomatic plants may be due to the bacteria's existence as cell wallless "L-forms" in plants. Growth and propagation of such modified bacteria in culture requires a specialized medium (75). Lacey could isolate L-forms of $R$. fascians only on Difco gelatin (56). If, as Vereecke et al. (103) speculate, $R$. fascians can live internally in plants as an L-form, it would be impossible to recover using standard isolation media.

Identification. Once a putative $R$. fascians culture has been recovered from a symptomatic plant, confirmation of identity can be problematic. It is difficult to distinguish Rhodococcus from other corynebacteria and to identify them to species using phenotypic characters $(9,99)$. Young (24 to $72 \mathrm{~h}$ ) cultures of $R$. fascians stain gram positive, but older cultures are gram variable or may even stain gram negative (58). Differentiation of $R$. fascians from

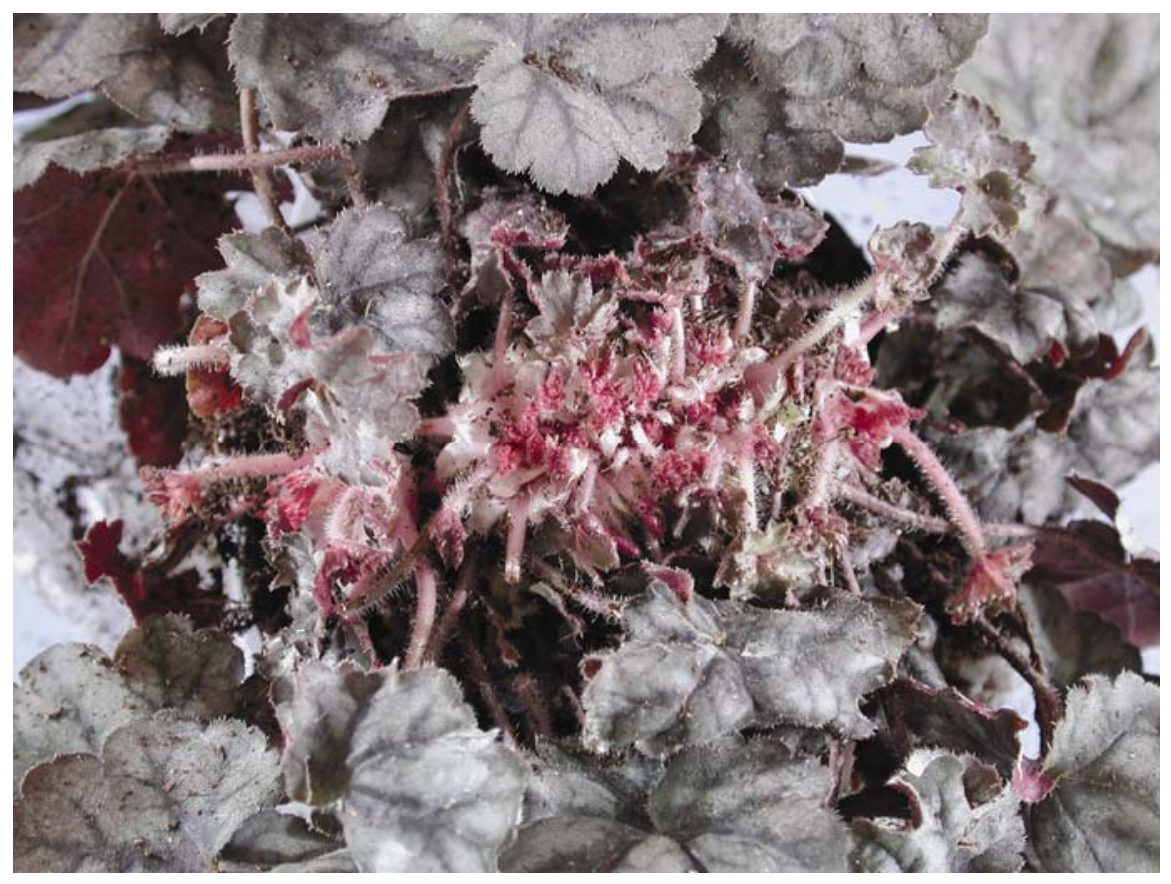

Fig. 9. Abnormal growth of Heuchera 'Hollywood' due to use of plant growth hormones. Such symptoms can be similar to those caused by Rhodococcus fascians. 
other coryneform bacteria is described in Schaad et al. (83) and Hu et al. (40). The analysis of cellular fatty acids has been used to identify $R$. fascians, as has carbon source utilization (available commercially from Biolog Inc., 21124 Cabot Blvd., Hayward, CA, 94545 USA). We have used Biolog extensively for identification of bacteria recovered from symptomatic plants, and we have found it to be unreliable for correctly identifying pure cultures of $R$. fascians. Other researchers have reported that Biolog is not useful for identification of $R$. fascians (37); even with substantial modification of the software, correct identification occurred only $67 \%$ of the time. Our experience with Biolog is such that it is used for identification of $R$. fascians only with significant experience and substantial caution.

Detection methods not reliant on bacterial recovery are available. Antisera have been raised against $R$. fascians $(24,66$,
$86,107)$ and used in indirect immunofluorescence antibody staining; antiserum is available commercially for this purpose (FLORILAB srl, Vocabolo Soriano 7, 06057 Montecastello di Vibio, (PG) Italy). DNA hybridization has been used to distinguish $R$. fascians from other coryneform bacteria (40).

The length of time involved in isolating, purifying, and identifying the recovered bacteria, plus inoculating a host to confirm pathogenicity, means that it can take months to confirm a diagnosis of $R$. fascians. This is an unacceptably long time for growers, who have a limited window of time during which they must propagate their plants in order to sell them in the upcoming season. To accommodate the needs of the growers and to streamline confirmation of $R$. fascians, we developed a PCR assay that targets the P450monooxygenase gene and fas- 1 region of the large linear plasmid, both of which are

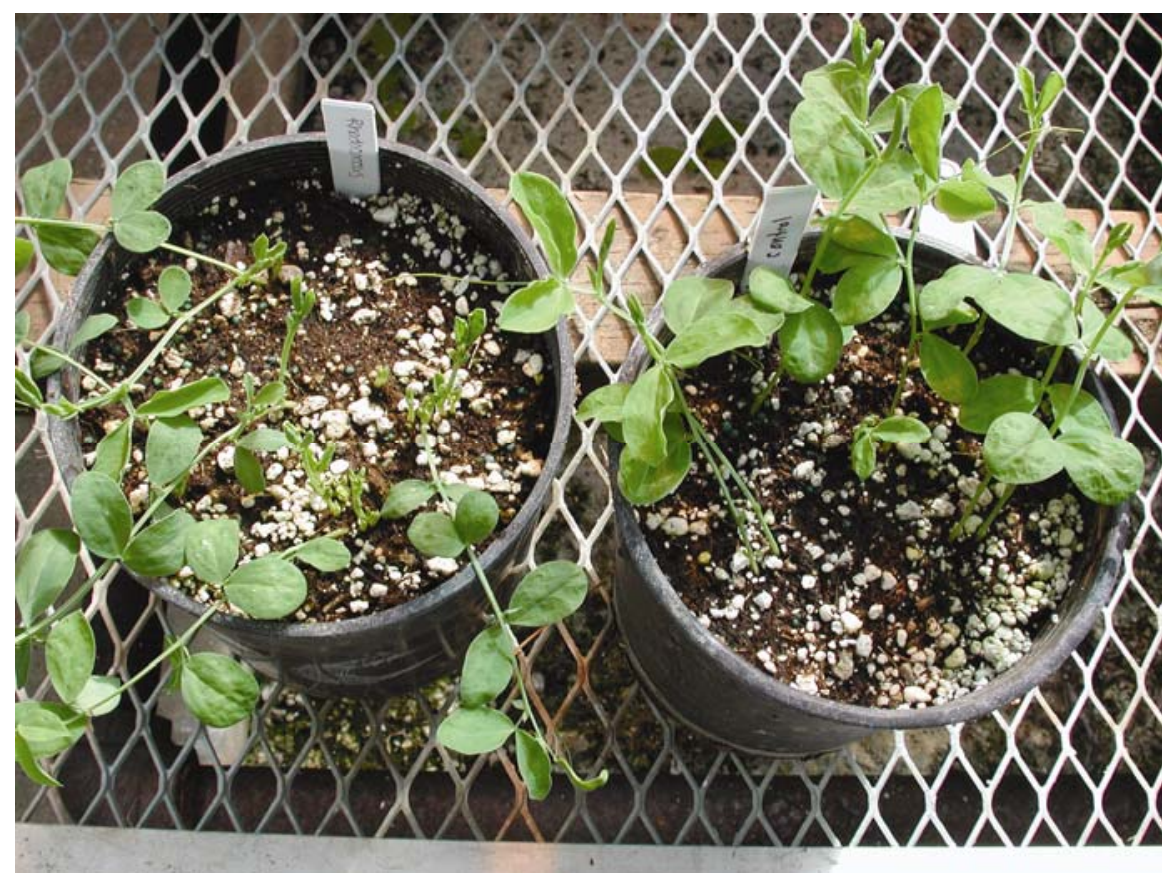

Fig. 10. Garden peas inoculated with Rhodococcus fascians (left) and uninoculated (right). Symptoms on peas consist primarily of small, distorted shoots and do not closely resemble those of many ornamental plants naturally infected with $R$. fascians.
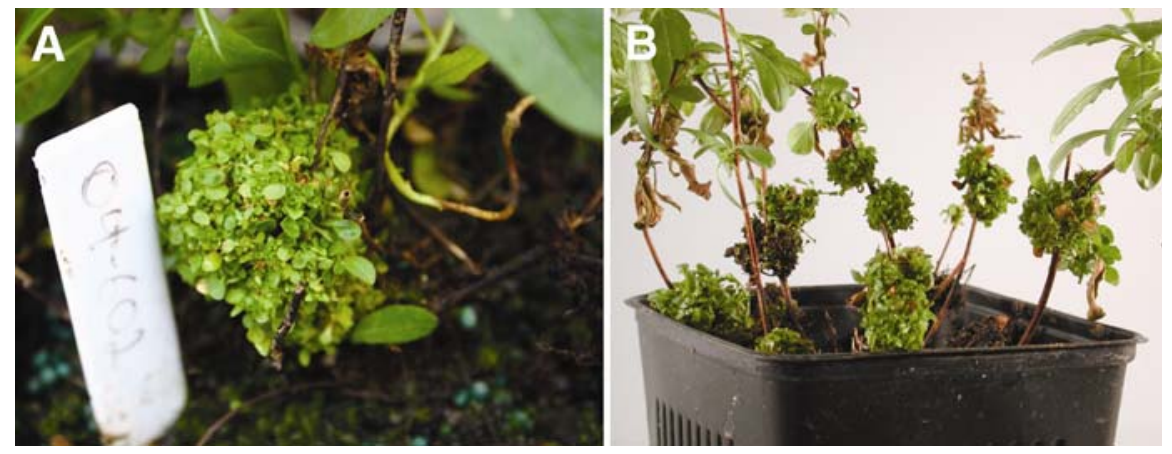

Fig. 11. A, Natural infection of Oenothera speciosa by Rhodococcus fascians. B, Inoculated $O$. speciosa. Symptoms resulting from artificial inoculation mimic those of naturally infected plants. required for virulence. These two primer sets have proven to be more reliable and specific for detection of the $R$. fascians isolates associated with herbaceous perennials than other published sequences $(33,89)$. We are currently verifying the accuracy and precision of this assay (67).

Host inoculation. Several methods have been used to inoculate plants. Lacey successfully inoculated surface-sterilized sweet peas by stabbing with a needle carrying bacteria or by pouring a bacterial suspension over the seeds and raising the plants axenically (50). Prick inoculations of sweet pea stems were unsuccessful. Other inoculation methods include pouring a bacterial suspension onto sterilized soil of potted plants $(31,52,101)$ or onto cuttings or plants $(52,101)$, planting in infested soil (96), submerging plants in a suspension of the bacteria followed by vacuum infiltration $(18,101)$, soaking roots in a suspension of macerated infected tissue (39), spotting a drop of bacterial suspension onto emerging radicles $(18,101)$, and spot inoculating young plants from which the apical meristems had been removed or left intact (101). Wounds are not needed for infection to take place $(52,53)$.

Sweet pea or garden pea seeds that have imbibed water and then been soaked with a bacterial suspension prior to potting will often show symptoms within 14 days (Fig. 10). Symptoms will not be similar to those observed on the original host, but peas are a rapid way to confirm pathogenicity of an isolate. We desired to more closely reproduce symptoms observed on herbaceous ornamentals and now use Oenothera speci$o s a$ as an indicator host (Fig. 11). Leafy galls form within 30 days when a suspension of actively growing bacteria is applied to young plants. Symptoms emerge earlier and more uniformly if plants are kept in a moist environment, such as within a plastic covering.

When inoculating to indicator hosts, younger plants are generally more susceptible than older plants $(31,50)$. It is wise to use a number of different host species since bacterial strains differ in their virulence $(31,50,52,66,100)$ and not all members of a genus are equally susceptible (68). There also may be host specificity in some bacterial strains (42), although this is not entirely clear.

\section{Challenges to Management}

$R$. fascians offers considerable challenges to the commercial grower. The pathogen may be present as long as 6 months before symptoms are apparent $(18,52,103)$, or symptoms may be relatively mild, misleading propagators into thinking they are working with healthy material. There is relatively little known regarding its epidemiology, nor have any modern control compounds been tested against the bacterium. Previous efforts have focused on hot water treatment of 
seeds and propagation material, soil disinfection, and topical applications of various substances for eradication of infected plant material and infested soil.

Hot water treatment of nasturtium (Tropaeolum spp.) seeds was effective when the seeds were heated to $52^{\circ} \mathrm{C}$ for 30 min (3), but nasturtium has a very large seed with a tough seed coat, and such extended times may injure plants with smaller and more tender seeds. A similar hot water treatment of Shasta daisy root divisions was a distinct failure: none of the roots survived the cure (3). Populations of $R$. fascians were reduced in lily (Lilium longiflorum) bulbs by immersion in $39^{\circ} \mathrm{C}$ water for $2 \mathrm{~h}$, with complete control achieved with the addition of $0.5 \%$ formalin (49). Formaldehyde or mercuric chloride has been used to sterilize seeds (96), but due to their toxicity, these chemicals are scarcely available now. Chastagner and Riley (15) investigated the potential of chlorine dioxide gas as a disinfectant of bulbs and cut flowers. They found a 1-h exposure at $25 \mathrm{ppm}$ chlorine dioxide killed all cells of $R$. fascians present on a glass surface. Additional studies are needed to determine the efficacy of the gas for disinfestation of bulbs and flowers.

Soil treatments have been used with varying success. Soil sterilization via steam (50) can eradicate the pathogen, and may have practical application in commercial greenhouses. Altering soil $\mathrm{pH}$ can be used to manage some soilborne pathogens, particularly fungi, but attempts to control $R$. fascians by acidifying soils to $\mathrm{pH} 5.0$ in Shasta daisy production resulted in death of the plants (3). Crop rotation to a nonhost for a year may help to reduce the populations of these bacteria in the soil (73).

Most growers are interested in a topical application of a curative compound to treat their plants, but little work has been done to determine the efficacy of chemicals traditionally used for control of bacterial diseases. Household bleach (sodium hypochlorite) will kill bacteria residing on plant surfaces, but some plants cannot stand such harsh treatment. Tender plants with leafy galls will not survive a dip of only 2 min in a $10 \%$ solution of commercial bleach. Baker found that even dilute solutions of bleach severely injured Shasta daisy root divisions (3). There is the additional problem of bleach not reaching bacteria residing in the interior plant tissues. Regular applications of streptomycin and oxyguinoline sulfate to cuttings of greenhouse geranium (Pelargonium sp.) reduced losses from $R$. fascians from 27 to $5 \%$ (60), although streptomycin use can delay rooting of cuttings (61). Further, the use of antibiotics in agriculture is somewhat controversial due to fears of increasing the populations of antibiotic resistant bacteria in the environment (64). Phyton 27, a formulation of copper sulfate pentahydrate, is a bactericide reportedly with some systemic activity. We have known growers to soak cuttings for $5 \mathrm{~min}$ in a $10 \%$ solution of Phyton 27 to prevent infection by $R$. fascians; some plants will not tolerate this treatment, and others suffer temporary injury. Copper is a known bactericide, but there are problems associated with its use, including phytotoxicity and development of resistance in populations of target bacteria. Additionally, copper-based and noncopper-based bactericides are not always successful in eradicating epiphytic bacterial pathogens from plants (84). There are a number of new compounds that might offer potential, including acidified hydrogen peroxide, host resistance activators, silver based products, aluminum tris, oxolinic acid, detergents, and phosphorus acids. None of these have been tested for efficacy against $R$. fascians. The bacterium Pseudomonas fluorescens strain A506, registered for control of fire blight (91), produces an antibiotic and in preliminary experiments caused inhibition of some $R$. fascians isolates in vitro (M. Miller and M. Putnam, unpublished), but the effect on growth of the pathogen was slight.

Currently, the primary means of disease management is prevention. Once bacteria are introduced into a production facility, strict sanitation is paramount. Strategies to be employed include culling of all affected plants; segregating new cuttings or stock plants from existing material; replacing stock plants after 6 or 8 months; disinfection of cutting tools between crops; use of quaternary ammonium-based disinfectants on hard surfaces such as greenhouse pots, flats, benches, floors, and other structures; and use of sterilized potting mixes. Other control measures are reviewed by Daughtrey and Benson (21) and Schnitzler (85). Slow sand filtration may be a viable option for treating recirculating water in greenhouse operations (85).

\section{Future Prospects}

Although there is a rich body of literature on the nature of the host-pathogen interaction in model systems, there is surprisingly little known of the basic biology of $R$. fascians. Although much might be inferred from other phytobacteria, $R$. fascians is a different beast in many respects, even from other hyperplasia-inducing bacteria: it does not require a wound to enter the plant, it does not preferentially enter through natural openings, and it may have a prolonged epiphytic phase prior to symptom expression. Much is unknown. Do Lforms exist in naturally infected plants? If so, they would thwart any topical chemical treatments. A. tumefaciens is known to be systemic in certain plants (e.g., Chrysanthemum and Argyranthemum) - are there plants in which $R$. fascians moves in the vascular system? Why is there an extended period between inoculation and symptom development in some plants? Is this medi- ated by environmental conditions, or is there a mechanism by which the bacterium switches from saprophytic to pathogenic growth? How long does $R$. fascians remain viable in the environment in the absence of a host? Do insects vector the pathogen in greenhouses or in field settings? Do cells of $R$. fascians organize themselves into biofilms? If so, what role do biofilms play in survival or pathogenesis? Can bactericides be used to eradicate populations already established on plant surfaces prior to penetration? Are bactericidal compounds effective in preventing disease once the bacteria have entered the host? Research into the basic biology and epidemiology of $R$. fascians would contribute to a greater understanding of the organism, which would allow more effective management decisions to be made.

Pathogenic $R$. fascians strains contain a conjugative linear plasmid, but the role of conjugation with avirulent strains has not been studied. In A. tumefaciens, in which virulence factors reside on the Ti plasmid, conjugation occurs in tumors between virulent and avirulent forms, leading to an increased number of pathogens $(45,46)$. There is evidence to support the transfer of Ti plasmid genes in the field to the biological control agent $A$. radiobacter $\mathrm{K} 84$. This has resulted in K84 transconjugants that carry genes for virulence (90). It would be interesting to study the possibility of in planta conjugation between virulent and avirulent strains of $R$. fascians on susceptible hosts and to investigate the resulting populations. The stability of the fasciationinducing ( $\mathrm{Fi}$ ) plasmid in $R$. fascians is unknown. Mohanty (70) remarked that some $R$. fascians strains known to be pathogenic after isolation no longer produced symptoms when inoculated years later. Sabart et al. found $R$. fascians isolates grown on a nutrient rich medium at $37^{\circ} \mathrm{C}$ could no longer produce symptoms on peas, although they were unsure if this was related to loss of the Fi plasmid or to deletions within it (82). A study to determine the conditions under which the $\mathrm{Fi}$ plasmid is lost or altered could be helpful in prevention of infection, or spread of pathogenic forms in the greenhouse.

The popularity of herbaceous perennials has driven changes in production practices in commercial nurseries. High volume propagation methods are used to keep up with demand for the plants. Plant hormones are used to stimulate increased branching to allow more cuttings, and plants are pushed heavily to produce as long as possible. $R$. fascians, in such a production system, can become established without the awareness of the grower. Symptoms of infection, particularly in the early stages, can be overlooked or mistaken for those associated with hormone applications. This article is one of a series of efforts in educational outreach to growers, extension personnel, consultants, and 
other professionals involved with growing, scouting, or diagnosing diseases to ensure that all involved understand the nature of the disease and the symptoms caused by $R$. fascians. Early detection and accurate diagnosis are instrumental in effective disease management.

\section{Acknowledgments}

We thank Danny Vereecke, Joyce Loper, Jennifer Krause, and Paul Reeser for critically reading the manuscript, Georges Lifermann for translation of the Faivre-Amiot paper, and the Oregon Department of Agriculture and the Oregon Association of Nurseries for financial assistance.

\section{Literature Cited}

1. Anonymous 2006. Floriculture Crops 2005 Summary (April 2006). USDA National Agricultural Statistics Service Sp Cr 6-1 (06).

2. Anonymous. 2006. Rhodococcus fascians. In: Crop Protection Compendium. CAB International, Wallingford, UK. (CD)

3. Baker, K. F. 1950. Bacterial fasciation disease

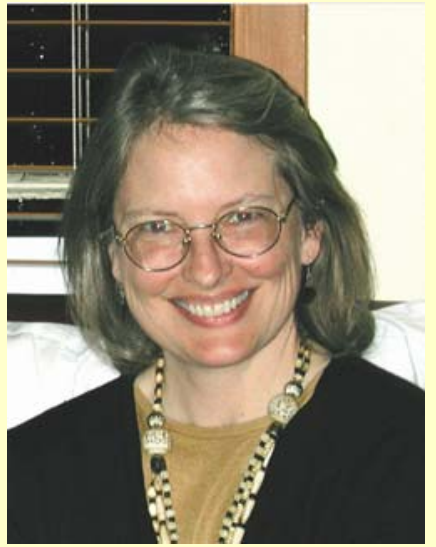

M. L. Putnam of ornamental plants in California. Plant Dis. Rep. 34:121-126.

4. Battikhi, M. N. 2002. Characterization of a coryneform isolate from fasciated mugwort (Artemisia vulgaris). New Microbiol. 25:187193.

5. Beattie, G. A., and Lindow, S. E. 1995. The secret life of foliar bacterial pathogens on leaves. Annu. Rev. Phytopathol. 33:145-172.

6. Bell, K. S., Kuyukina, M. S., Heidbrink, S., Philp, J. C., Aw, D. W. J., Ivshina, I. B., and Christofi, N. 1999. Identification and environmental detection of Rhodococcus species by 16S rDNA-targeted PCR. J. Appl. Microbiol. 87:472-480.

7. Bell, K. S., Philp, J. C., Aw, D. W. J., and Christofi, N. 1998. The genus Rhodococcus. J. Appl. Microbiol. 85:195-210.

8. Bergström, I. 1943. Fasciation bacteriosis of melon and other plants. Rev. Appl. Mycol. 22:89.

9. Bizet, C., Barreau, C., Harmant, C., Nowakowski, M., and Pietfroid, A. 1997. Identification of Rhodococcus, Gordona and Dietzia species using carbon source utilization tests ("Biotype-100" strips). Res. Microbiol.

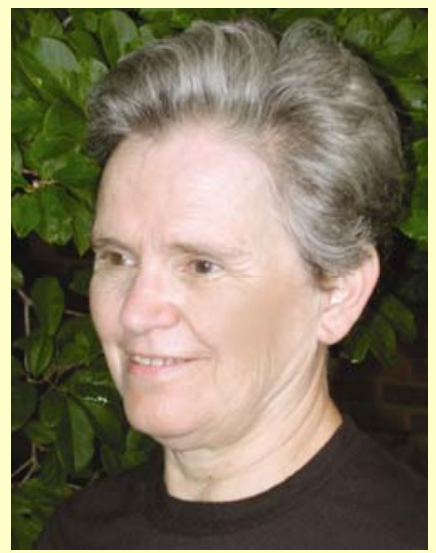

M. L. Miller
Melodie Putnam was abandoned by her parents at a young age in a tragic error, when her parents moved and she was left behind, mistaken for a bag of potatoes. Through fortuitous circumstances, she was adopted by itinerate apostate missionaries who had rededicated their lives to radical vegetarianism. Melodie prefers meat. She put herself through University and earned an M.S. degree from the University of Wisconsin investigating epidemiology of soilborne diseases of ginseng. She has been working in plant disease diagnostics for nearly 25 years, her adoptive parents having instilled in her a reverence for plants. Melodie has been at Oregon State University since 1993. She has been investigating bacterial diseases of herbaceous perennials for about six years, focusing primarily on Rhodococcus fascians. Melodie has served APS in diverse capacities, at both the national and divisional level, and is currently councilor of the Pacific Division and sits on the advisory board of Plant Management Network.

Marilyn Miller is a senior faculty research assistant in the Department of Botany and Plant Pathology at Oregon State University. She received her B.A. and M.A. degrees in biology from California State University, Fullerton, and was a Ph.D. student in the Department of Plant Pathology at Oregon State University. Marilyn has worked on Pseudomonas blight in nursery crops and is one of the few researchers remaining who has extensive experience with crown gall in nursery and fruit crops, the result of over 25 years of investigation. Since 2002, she has been conducting research on the host range and epidemiology of Rhodococcus fascians. Her main research interests have been in biological control of bacterial diseases, prevention of crown gall in Oregon vineyards, use of soil solarization to reduce disease incidence, use of micropropagated plants as model systems for pathogenicity testing, and enhanced methods for diagnosing bacterial diseases in nursery crops. She has been a long-time member of APS and served on the Women in Plant Pathology Committee and the Bacteriology Committee.
148:799-809.

10. Boylen, C. W., and Mulks, M. H. 1978. The survival of coryneform bacteria during periods of prolonged nutrient starvation. J. Gen. Microbiol. 105:323-334.

11. Bradbury, J. F. 1967. Corynebacterium fas cians. CMI Descriptions of Pathogenic Fung \& Bacteria. No 121. Commonwealth Agricultural Bureaux. The Eastern Press Ltd., London.

12. Bradbury, J. F. 1986. Guide to Plant Pathogenic Bacteria. CAB International Mycological Institute, Surrey, England.

13. Brown, N. A. 1927. Sweet pea fasciation, a form of crowngall. Phytopathology 17:29-32.

14. Buchwald, N. F. 1946. Fasciation bacteriosis (Bacterium fascians (Tilford) Lacey). A new bacterial disease for Denmark. Rev. Appl Mycol. 25:68.

15. Chastagner, G. A, and Riley, K. L. 2005. Sensitivity of pathogen inocula to chlorine dioxide gas. Acta Hortic. 673:355-359.

16. Cooksey, D. A., and Keim, R. 1983. Association of Corynebacterium fascians with fasciation disease of Impatiens and Hebe in California. Plant Dis. 67:1389.

17. Cornelis, K., Maes, T., Jaziri, M., Holsters, M., and Goethals, K. 2002. Virulence genes of the phytopathogen Rhodococcus fascians show specific spatial and temporal expression patterns during plant infection. Mol. PlantMicrobe Interact. 15:398-403.

18. Cornelis, K., Ritsema, T., Nijsse, J., Holsters M., Goethals, K., and Jaziri, M. 2001. The plant pathogen Rhodococcus fascians colonizes the exterior and interior of the aerial parts of plants. Mol. Plant-Microbe Interact. 14:599-608.

19. Crespi, M., Messens, E., Caplan, A. B., Van Montagu, M., and Desomer, J. 1992. Fasciation induction by the phytopathogen Rhodococcus fascians depends upon a linear plasmid encoding a cytokinin synthase gene. EMBO J. 11:795-804.

20. Crespi, M., Vereecke, D., Temmerman, W., Van Montagu, M., and Desomer, J. 1994. The fas operon of Rhodococcus fascians encodes new genes required for efficient fasciation of host plants. J. Bacteriol. 176:2492-2501.

21. Daughtrey, M. L., and Benson, D. M. 2005 Principles of plant health management for ornamental plants. Annu. Rev. Phytopathol. 43:141-169.

22. De Cleene, M., and De Ley, J. 1976. The host range of crown gall. Bot. Rev. 42:389-466.

23. Desomer, J., Crespi, M., and Van Montagu, M. 1991. Illegitimate integration of non-replicative vectors in the genome of Rhodococcus fascians upon electro-transformation as an insertional mutagenesis system. Mol. Microbiol. 5:2115-2124.

24. Digat, B. 1978. Sélection sanitaire des boutures de Pelargonium et de Begonia $\times$ Elatior 'Rieger' vis-à-vis des bactérioses par utilisation de l'immunofluorescence. Ann. Phytopathol. 10:67-78

25. Dowson, W. J. 1957. Plant Diseases Due to Bacteria; 2nd ed. Cambridge University Press, London.

26. Eason, J. R., Jameson, P. E., and Bannister, P. 1995. Virulence assessment of Rhodococcus fascians strains on pea cultivars. Plant Pathol. 44:141-147.

27. Eason, J. R., Morris, R. O., and Jameson, P. E. 1996. The relationship between virulence and cytokinin production by Rhodococcus fascians (Tilford 1936) Goodfellow 1984. Plant Pathol. 45:323-331.

28. Elia, S., Gosselé, F., Genetello, C., Swings, J., Van Montagu, M., and De Lay, J. 1983 Phenotypic and phytopathological characterization of Corynebacterium fascians. Meded. Faculteit Landbouww. Rijk. Gent 48:677-683.

29. Elia, S., Gosselé, F., Vantomme, R., Swings, 
J., and De Lay, J. 1984. Corynebacterium fascians: Phytopathogenicity and numerical analysis of phenotypic features. Phytopathol. Z. 110:89-105.

30. Elo, S., Maunuksela, L., Salkinoja-Salonen, M., Smolander, A., and Haahtela, K. 2000. Humus bacteria of Norway spruce stands: Plant growth promoting properties and birch, red fescue and alder colonizing capacity. FEMS Microbiol. Ecol. 31:143-152.

31. Faivre-Amiot, A. 1967. Quelques observations sur la présence de Corynebacterium fascians (Tilford) Dowson dans les cultures maraichères et florales en France. PhytiatriePhytopharamacie 16:165-176.

32. Finnerty, W. R. 1992. The biology and genetics of the genus Rhodococcus. Annu. Rev. Microbiol. 46:193-218.

33. Galis, I., Bilyeu, K., Wood, G., and Jameson, P. E. 2005. Rhodococcus fascians: Shoot proliferation without elevated cytokinins? Plant Growth Regul. 46:109-115.

34. Geneve, R. 1990. Fascinated with fasciation. Am. Hortic. 69:27-31.

35. Goethals, K., Vereecke, D., Jaziri, M., Van Montagu, M., and Holsters, M. 2001. Leafy gall formation by Rhodococcus fascians. Annu. Rev. Phytopathol. 39:27-52.

36. Gürtler, V., Mayall, B. C., and Seviour, R. 2004. Can whole genome analysis refine the taxonomy of the genus Rhodococcus? FEMS Microbiol. Rev. 28:377-403.

37. Harris-Baldwin, A., and Gudmestad, N. C. 1996. Identification of phytopathogenic coryneform bacteria using the Biolog automated microbial identification system. Plant Dis. 80:874-878.

38. Holt, J. G., Krieg, N. R., Sneath, P. H. A., Staley, J. T., and Williams, S. T., eds. 1994. Bergey's Manuel of Determinative Bacteriology, 9th ed. Williams \& Wilkins, Baltimore, MD.

39. Hoof, H. A. v., Huttinga, H., Knaap, A., Maas Geesteranus, H. P., Mosch, W. H. M., and de Raay-Wieringa, D. G. J. 1979. Tumors of Begonia and some other ornamentals, induced by Corynebacterium fascians. Neth. J. Plant Pathol. 85:87-98.

40. Hu, F.-P., Fletcher, M. J., Watson, D. R. W., Clark, R. G., and Young, J. M. 1992. Identification of Rhodococcus fascians (Tilford 1936) Goodfellow 1984. J. Phytopathol. 136:37-45.

41. Jacobs, S. E., Habish, H. A., and Dadd, A. H. 1965. Studies on induced mutants of Corynebacterium fascians and on their pathogenicity in comparison with that of 'natural' strains. Ann. Appl. Biol. 56:161-170.

42. Jacobs, S. E., and Mohanty, U. 1951. Studies in Bacteriosis, XXVII. Factors influencing infection by Corynebacterium fascians (Tilford) Dowson. Ann. Appl. Biol. 38:237-245.

43. Jones, E. G., Catton, F. W., and Bateson, M. 1977. Root galls on raspberry. Plant Pathol. 26:96-97.

44. Kado, C., and Heskett, M. G. 1970. Selective medium for isolation of Agrobacterium, Corynebacterium, Erwinia, Pseudomonas and Xanthomonas. Phytopathology 60:969976.

45. Kerr, A. 1969. Transfer of virulence between isolates of Agrobacterium. Nature 223:11751176.

46. Kerr, A. 1971. Acquisition of virulence by non-pathogenic isolates of Agrobacterium radiobacter. Physiol. Plant Pathol. 1:241-246.

47. Kers, J. A., Cameron, K. D., Joshi, M. V., Burkhalid, R. A., Morello, J. E., Wach, M. J., Gibson, D. M., and Loria, R. 2005. A large, mobile pathogenicity island confers plant pathogenicity on Streptomyces species. Mol. Microbiol. 55:1025-1033.

48. Khoga, J. M., Tóth, E., Márialigeti, K., and Borossay, J. 2002. Fly attracting volatiles pro- duced by Rhodococcus fascians and Mycobacterium aurum isolated from myiatic lesions of sheep. J. Microbiol. Methods 48:281287.

49. Kruyer, C. J., and Boontjes, J. 1982. De warmwaterbehandeling van Lilium longiflorum. Bloembollencultuur 93:622-623.

50. Lacey, M. S. 1936. Studies in Bacteriosis XXII. I. The isolation of a Bacterium associated with "fasciation" of sweet peas, "cauliflower" strawberry plants and "leafy gall" of various plants. Ann. Appl. Biol. 23:302-310.

51. Lacey, M. S. 1936. Studies in Bacteriosis XXIII. Further studies on a bacterium causing fasciation of sweet peas. Ann. Appl. Biol. 23:743-751

52. Lacey, M. S. 1939. Studies in Bacteriosis XXIV. Studies on a bacterium associated with leafy galls, fasciations and "cauliflower" disease of various plants. Part III. Further isolations, inoculation experiments and cultural studies. Ann. Appl. Biol. 26:262-278.

53. Lacey, M. S. 1942. Studies in Bacteriosis. XXV. Studies on a bacterium associated with leafy-galls, fasciations and 'cauliflower' disease of various plants. Part IV. The inoculation of strawberry plants with Bacterium fascians (Tilford.). Ann. Appl. Biol. 29:11-15.

54. Lacey, M. S. 1948. Studies on Bacterium fascians. V. Further observations on the pathological and physiological reactions of Bact. fascians. Ann. Appl. Biol. 35:572-581.

55. Lacey, M. S. 1955. The cytology and relationships of Corynebacterium fascians. Trans. Br. Mycol. Soc. 38:49-58.

56. Lacey, M. S. 1961. The development of filterpassing organisms in Corynebacterium fascians cultures. Ann. Appl. Biol. 49:634-644.

57. Larkin, M. J., De Mot, R., Kulakov, L. A., and Nagy, I. 1998. Applied aspects of Rhodococcus genetics. Anton. Leeuw. 74:133-153.

58. Lelliott, R. A., and Stead, D. E. 1987. Methods in Plant Pathology. Vol. 2. Methods for the Diagnosis of Bacterial Diseases of Plants. British Society for Plant Pathology. Blackwell Scientific, London.

59. Lin, T.-C., Ibaraki, M., Osabe, M., Yan, L., Jaziri, M., and Ishimaru, K. 2003. Fasciated shoot formation and the secondary metabolites in Pratia nummularia infected with Rhodococcus fascians. Chinese Pharm. J. 5:141-146.

60. Maas Geesteranus, H. P. 1963. Corynebacterium fascians bij Pelargonium zonale. Jaarverslag 1962, Instituut voor Plantenzicktenkundig Onderzock, Wageningen.

61. Maas Geesteranus, H. P. 1965. Corynebacterium fascians bij Pelargonium zonale. J. M. Krijthe, ed. Jaarverslag 1964, Instituut voor Plantenziektenkundig Onderzoek, Wageningen.

62. Manes, C.-L. de O., Beeckman, T., Ritsema, T., Van Montagu, M., Goethals, K., and Holsters, M. 2004. Phenotypic alterations in Arabidopsis thaliana plants caused by Rhodococcus fascians infections. J. Plant Res. 117:139-145.

63. Manes, C.-L. de O., Van Montagu, M., Prinsen, E., Goethals, K., and Holsters, M. 2001. De novo cortical cell division triggered by the phytopathogen Rhodococcus fascians in tobacco. Mol. Plant-Microbe Interact. 14:189195.

64. McManus, P. S., Stockwell, V. O., Sundin, G. W., and Jones, A. L. 2002. Antibiotic use in plant agriculture. Annu. Rev. Phytopathol. 40:443-465.

65. Mergaert, J., Verhelst, A., Cnockaert, M. C., Tan, T.-L., and Swings, J. 2001. Characterization of facultative oligotrophic bacteria from polar seas by analysis of their fatty acids and 16S rDNA sequences. Syst. Appl. Microbiol. 24:98-107.
66. Miller, H. J., Janse, J. D., Kamerman, W., and Muller, P. J. 1980. Recent observations on leafy gall in Liliaceae and some other families. Neth. J. Plant Pathol. 86:55-68.

67. Miller, M., Collins, K., Kraus, J., and Putnam, M. L. 2006. PCR detection of pathogenic Rhodococcus fascians and Agrobacterium tumefaciens on herbaceous perennials. (Abstr.) Phytopathology 96:S79.

68. Miller, M., and Putnam, M. L. 2005. Isolation of Agrobacterium and Rhodococcus from herbaceous perennials with tumors, shoot proliferation, and leafy galls. (Abstr.) Phytopathology 95:S70.

69. Miteva, V. I., Sheridan, P. P., and Brenchley, J. E. 2004. Phylogenetic and physiological diversity of microorganisms isolated from a deep Greenland glacier ice core. Appl. Environ. Microbiol. 70:202-213.

70. Mohanty, U. 1951. Corynebacterium fascians (Tilford) Dowson; its morphology, physiology, nutrition and taxonomic position. Trans Br. Mycol. Soc. 34:23-34.

71. Moore, W. C. 1943. Report on fungus, bacterial and other diseases of crops in England and Wales for the years 1933-1942. Ministry of Agriculture and Fisheries Bull. No. 126, London.

72. Muncie, J. H., and Patel, M. K. 1930. Fasciation of sweet peas. Am. J. Bot. 17:218-230.

73. Oduro, K. A. 1975. Factors affecting epidemiology of bacterial fasciation of Chrysanthemum maximum. Phytopathology 65:719721.

74. Pape, H. 1938. Eine noch wenig beachtete Krankheit der Zierpflanzen. Der Blumen-und Pflanzenbau die Gartenwelt 42:384-386.

75. Pelczar, M. J., Jr., Reid, R. D., and Chan, E. C. S., eds. 1977. Microbiology. 4th ed McGraw-Hill Book Company, New York.

76. Pennycook, S. R. 1989. Plant diseases recorded in New Zealand. Vol. 3. Plant Diseases Division, DSIR, Auckland, NZ

77. Pisabarro, A., Correia, A., and Martin, J. F. 1998. Pulsed-field gel electrophoresis analysis of the genome of Rhodococcus fascians: Genome size and linear and circular replicon composition in virulent and avirulent strains. Curr. Microbiol. 36:302-308.

78. Prasad, N. S., Rao, A. R., and Rao, G. M. 1997. Fasciation in Casuarina equisetifolia. Indian Forester 123:773-774

79. Prebble, J. 1968. The carotenoids of Corynebacterium fascians strain 2 Y. J. Gen. Microbiol. 52:15-24.

80. Putnam, M. L., and Miller, M. 2006. Pathogenic isolates of Rhodococcus fascians from new hosts in the United States. Plant Dis. $90 \cdot 526$

81. Quoirin, M., Bona, C., de Souza, E. F., and Schwartsburd, P. B. 2004. Induction of leafy galls in Acacia mearnsii De Wild seedlings infected by Rhodococcus fascians. Braz. Arch. Biol. Technol. 47:339-346.

82. Sabart, P. R., Gakovich, D., and Hanson, R S. 1986. Avirulent isolates of Corynebacte rium fascians that are unable to utilize agmatine and proline. Appl. Environ. Microbiol. 52:33-36.

83. Schaad, N. W., Jones, J. B., and Chun, W., eds. 2001. Laboratory Guide for Identification of Plant Pathogenic Bacteria. 3rd ed American Phytopathological Society, St Paul, MN.

84. Scheck, H., and Pscheidt, J. W. 1998. Effect of copper bactericides on copper-resistant and -sensitive strains of Pseudomonas syringae pv. syringae. Plant Dis. 82:397-406.

85. Schnitzler, W. H. 2004. Pest and disease management of soilless culture. Acta Hortic. 648:191-203.

86. Scortichini, M., Todisco, C., and Varvaro, L. 1990. Specificity of antisera against Rhodo coccus fascians (Tilford) Goodfellow in indi- 
rect immunofluroscence. J. Phytopathol. 129:327-332.

87. Smith, E. F. 1916. Crowngall studies showing changes in plant structures due to a changed stimulus. J. Agric. Res. VI 179-193.

88. Smith, E. F. 1922. Fasciation and prolepsis due to crown gall. Phytopathology 12:265270 .

89. Stange, R. R., Jeffares, D., Young, C., Scott, D. B., Eason, J. R., and Jameson, P. E. 1996. PCR amplification of the fas- 1 gene for the detection of virulent strains of Rhodococcus fascians. Plant Pathol. 45:407-417.

90. Stockwell, V. O., Kawalek, M. D., Moore, L. W., and Loper, J. E. 1996. Transfer of pAgK84 from the biocontrol agent Agrobacterium radiobacter $\mathrm{K} 84$ to A. tumefaciens under field conditions. Phytopathology 86:3137.

91. Stockwell, V. O., and Stack, J. P. 2007. Using Pseudomonas spp. for integrated biological control. Phytopathology 97:244-249.

92. Süle, S. 1977. Bacterial fasciation of Pelargonium hortorum in Hungary. Acta Phytopathol. Acad. Sci. Hung. 11:223-230.

93. Sundin, G. W., and Jacobs, J. L. 1999. Ultraviolet radiation (UVR) sensitivity analysis and UVR survival strategies of a bacterial community from the phyllosphere of fieldgrown peanut (Arachis hypogeae L.). Microb. Ecol. 38:27-38.
94. Takayama, M., Kawai, A., and Suetsugu, T. 1985. Studies on the diagnosis of foreign bacterial diseases of quarantine significance. V. A selective medium for isolation and detection of Corynebacterium fascians. Res. Bull. Plant Prot. Serv. Jpn. No. 21:33-40.

95. Thimann, K. V., and Sachs, T. 1966. The role of cytokinins in the "fasciation" disease caused by Corynebacterium fascians. Am. J. Bot. 53:731-739.

96. Tilford, P. E. 1936. Fasciation of sweet peas caused by Phytomonas fascians n. sp. J. Agric. Res. 53:383-394.

97. Tóth, E. M., Hell, É., Kovács, G., Borsodi, A. K., and Márialigeti, K. 2006. Bacteria isolated from the different developmental stages and larval organs of the obligate parasitic fly, Wohlfahrtia magnifica (Diptera: Sarcophagidae). Microb. Ecol. 51:13-21.

98. Ulrychová, M., and Petrů, E. 1983. Isolation of some strains of Corynebacterium fascians (Tilford) Dowson in Czechoslovakia. Biol. Plant. (Praha) 25:63-67.

99. Valdés-Stauber, N., Scherer, S., and Seiler, H. 1997. Identification of yeasts and coryneform bacteria from the surface microflora of brick cheeses. Int. J. Food Microbiol. 34:115-129.

100. Vantomme, R., Elia, S., Swings, J., and DeLey, J. 1982. Corynebacterium fascians (Tilford 1936) Dowson 1942 the causal agent of leafy gall on lily crops in Belgium. Para- sitica 38:138-192.

101. Vereecke, D., Burssens, S., Simón-Mateo, C. Inzé, D., Van Montagu, M., Goethals, K., and Jaziri, M. 2000. The Rhodococcus fasciansplant interaction: Morphological traits and biotechnical applications. Planta 210:241251.

102. Vereecke, D., Cornelius, K., Temmerman, W., Jaziri, M., Van Montagu, M., Holsters, M. and Goethals, K. 2002. Chromosomal locus that affects pathogenicity of Rhodococcus fascians. J. Bacteriol. 184:1112-1120.

103. Vereecke, D., Temmerman, W., Jaziri, M., Holsters, M., and Goethals, K. 2003. Toward an understanding of the Rhodococcus fascians-plant interaction. Plant Microbe Interactions. Vol 6. G. Stacy and N. Kean, eds. American Phytopathological Society, St Paul, MN.

104. Warhurst, A. M., and Fewson, C. A. 1994 Biotransformations catalyzed by the genus Rhodococcus. Crit. Rev. Biotechnol. 14:29-73.

105. Williams, P. H. 1933. Leafy gall of Chrysanthemum. Rev. Appl. Mycol. 12:698-699.

106. Williams, P. H. 1934. Leafy gall of Chrysanthemum. Rev. Appl. Mycol. 13:638.

107. Zutra, D., Cohen, J., Gera, A., and Loebenstein, G. 1994. Association of Rhodococcus (Corynebacterium) fascians with the stunting-fasciation syndrome of carnation in Israel. Acta Hortic. 377:319-323. 